Pezhman Akbari

e-mail: akbari@iupui.edu

Razi Nalim

e-mail: mnalim@iupui.edu

Department of Mechanical Engineering, Purdue School of Engineering and Technology, Indianapolis, IN 46202-5132

\author{
Norbert Mueller \\ Department of Mechanical Engineering, \\ Michigan State University, \\ 2455 Engineering Building, \\ East Lansing, Ml 48824-1226 \\ e-mail: mueller@egr.msu.edu
}

\section{A Review of Wave Rotor Technology and Its Applications}

The objective of this paper is to provide a succinct review of past and current research in developing wave rotor technology. This technology has shown unique capabilities to enhance the performance and operating characteristics of a variety of engines and machinery utilizing thermodynamic cycles. Although there have been a variety of applications in the past, this technology is not yet widely used and is barely known to engineers. Here, an attempt is made to summarize both the previously reported work in the literature and ongoing efforts around the world. The paper covers a wide range of wave rotor applications including the early attempts to use wave rotors, its successful commercialization as superchargers for car engines, research on gas turbine topping, and other developments. The review also pays close attention to more recent efforts: utilization of such devices in pressure-gain combustors, ultra-micro gas turbines, and water refrigeration systems, highlighting possible further efforts on this topic. Observations and lessons learnt from experimental studies, numerical simulations, analytical approaches, and other design and analysis tools are presented. [DOI: 10.1115/1.2204628]

\section{Introduction}

Oscillatory and pulsatile fluid motion is ubiquitous in Nature, yet is relatively poorly studied by engineers despite the invention of cyclically operating engines and machines. The potential for utilizing unsteady flows has been recognized since the early twentieth century, but has been neglected as long as substantive improvements could be made to conceptually simple semi-static devices, steady-flow devices, or crypto-steady devices (having flow that is steady in a particular frame of reference, e.g., turbomachines). Further, the inherent nonlinearity of large-amplitude wave phenomena in compressible fluids necessitates detailed flow calculations, which until recently were too laborious, expensive, or imprecise. By understanding and exploiting complex unsteady flows, significantly better engines and thermodynamic cycles can be enabled for various applications.

Shock tubes, shock tunnels, pulse combustors, pulse detonation engines, and wave rotors are a few examples of unsteady-flow devices. The basic concept underlying these devices is the transfer of energy by pressure waves. By generating compression and expansion waves in appropriate geometries, wave machines can transfer energy directly between different fluids without using mechanical components such as pistons or vaned impellers. The major benefits of these unsteady-flow machines is their potential to generate large pressure changes in short time or distance [1,2], and to tolerate transient peak fluid pressures and temperatures that exceed continuous exposure limits. Furthermore, wave compression is a relatively efficient process at moderate pressure ratios as shown in Fig. 1, where shock isentropic efficiency $\eta_{\text {Shock }}($ red) is compared with compressor isentropic efficiency $\eta_{\text {Compressor }}$ (green) and subsonic diffuser isentropic efficiency $\eta_{\text {Diffuser }}$ (blue). Figure 1 shows variations of these parameters as functions of the pressure gain $p_{2} / p_{1}$ obtained by a moving shock wave in a frictionless channel, by a compressor with different values of polytropic efficiencies, and by a diffuser with different values of total pressure drop expressed by $p_{t 2} / p_{t 1}$, respectively. The comparison reveals that for the same pressure gain $p_{2} / p_{1}$, the ideal shock compression efficiency may significantly exceed the efficiency obtained by a typical diffuser or compressor. Flow friction effects would lower the efficiency of wave devices [3] and reduces their

Submitted to ASME for publication in the Journal of ENGINEERING FOR GAS TuRBINES AND POWER. Manuscript received December 7, 2004; final manuscript received January 19, 2006. Review conducted by R. P. Shreeve. efficiency advantage (not shown in Fig. 1), but the relative advantage is expected to persist. As an example, Ref. [4] has investigated a feasibility study of replacing conventional diffusers used in centrifugal compressors with the wave augmented diffuser.

\section{Wave Rotor Machines}

The essential feature of a wave rotor is an array of channels arranged around the axis of a cylindrical drum. As schematically shown in Fig. 2, the drum rotates between two stationary end plates, each of which has a few ports or manifolds, controlling the fluid flow through the channels. Through rotation, the channel ends are periodically exposed to differing port pressures, initiating compression, and expansion waves within the wave rotor channels. The number of ports and their positions vary for different applications. By carefully selecting their locations and widths to generate and utilize wave processes, a significant and efficient transfer of energy can be obtained between flows in the connected ducts. Thus, pressure is exchanged dynamically between fluids by utilizing unsteady pressure waves. Unlike a steady-flow turbomachine that either compresses or expands the fluid, the wave rotor accomplishes both compression and expansion within a single component. To minimize leakage, the gap between the end plates and the rotor has to be very small, but without contact under all operating and thermal expansion conditions. An inverted design with stationary channels and rotating ports is also possible [5]. Such a configuration may be preferred for laboratory investigations for easy flow measurement in the channels where the important dynamic interactions take place. In practical design, this arrangement is mechanically inconvenient [6].

Most designs use straight axial channels, but curved channels can be used to create a "wave turbine" that produces shaft power. With axial channels and matched port flow alignment, the power required to keep the rotor at a correctly designed speed is negligible $[6,7]$, as it only needs to overcome rotor windage and friction. In such a configuration, the rotor may be gear or belt driven or preferably direct driven by an electrical motor (not shown). Alternatively, a self-driving configuration, known as the "freerunning rotor," can drive itself by using port flow incidence on channel walls to turn the rotor $[8,9]$.

There are several important advantages of wave rotor machines relative to competing turbomachines particularly for straightchannel rotors with no shaft power transfer. Wave rotor flows can respond on the time scale of pressure waves with no rotational inertia lag. Their rotational speed is low compared with turboma- 


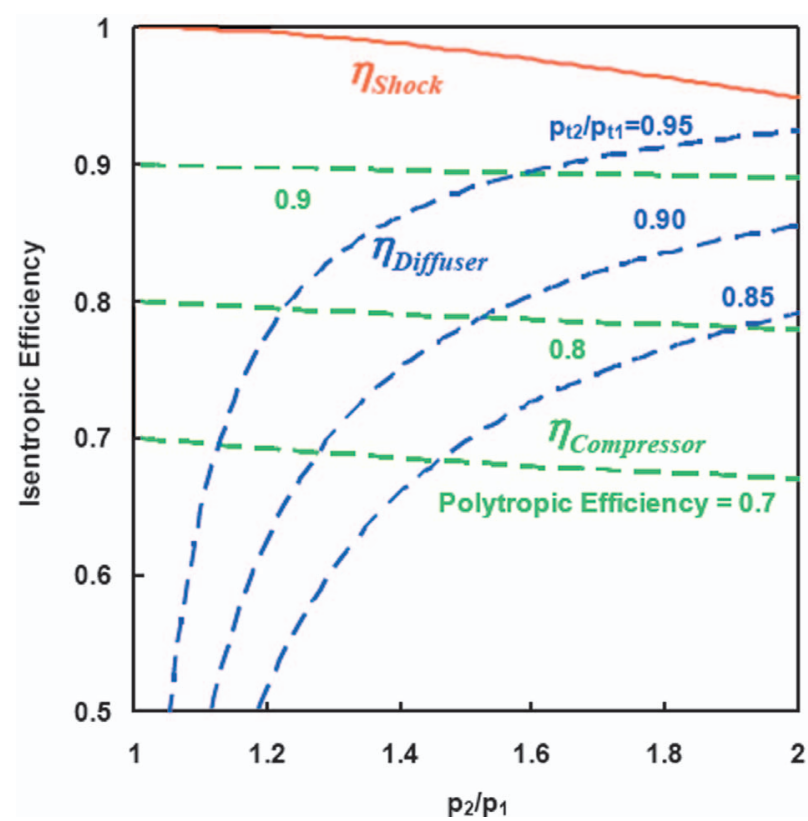

Fig. 1 Shock wave, compressor, and diffuser isentropic efficiencies as functions of pressure gain

chines, unless designed for shaft power generation, which should result in low material stresses. However, the tip shroud offsets this advantage somewhat, and the design must safeguard against fatigue-induced failures in surfaces subjected to cyclic pressure fluctuations. Wave rotor geometry can be mechanically simpler than those of turbomachines, allowing inexpensive manufacture. In addition the rotor channels are less prone to erosion damage than the blades of turbomachines. This is mainly due to the lower velocity of the working fluid in the channels, which is about onethird of what is typical within turbomachines [6] and the absence of flow turning. Another important advantage of wave rotors is their self-cooling capability. In heat engine applications, the rotor channels pass both cool air (being compressed) and hot gas (being expanded) in the cycle at least once per rotor revolution, alternating faster than thermal diffusion rates, allowing peak cycle temperature above materials limits. The rotor temperature equilibrates between the temperature of the cooler air and the hotter gas, but may retain axial and radial temperature variation that limits strength and distorts sealing surfaces.

Despite generally attractive features, several challenges have impeded the extensive commercial appearance of wave rotors. Numerous research efforts have been carried out during the past century to understand the complex unsteady flow and creatively select the best wave rotor configuration for a particular application. The obstacles have been mainly of a mechanical nature, such as sealing and thermal expansion issues, as mentioned frequently in this review. Nevertheless, continued impetus for energy effi-

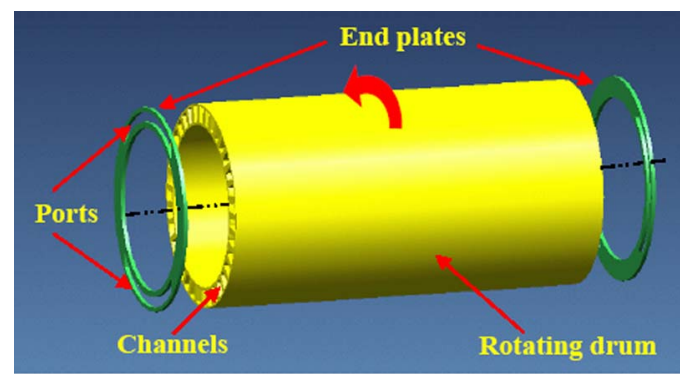

Fig. 2 Schematic configuration of a typical wave rotor

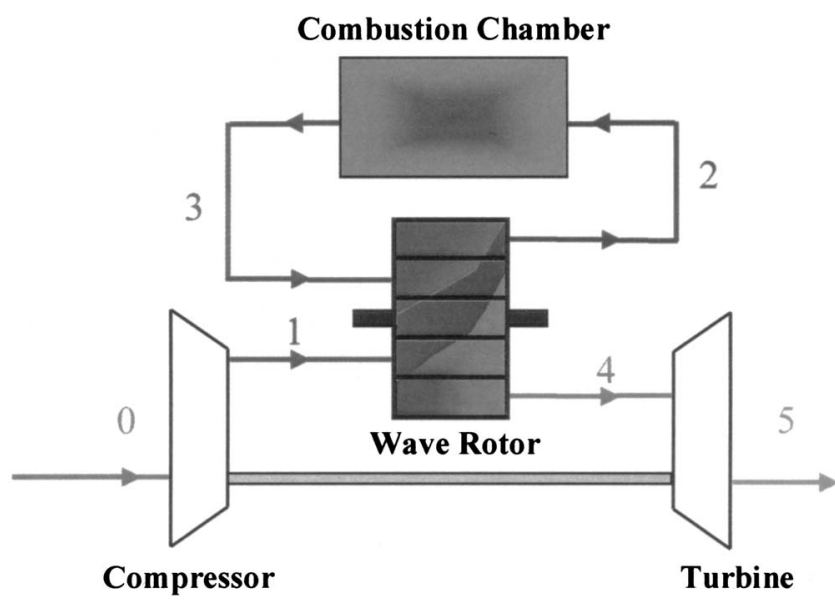

Fig. 3 Schematic of a gas turbine topped by a through-flow four-port wave rotor

ciency, diminishing advances of older technology, and marketplace changes have stimulated new interest in wave rotor technology.

Four-Port Pressure-Exchange Wave Rotor Examples. A variety of wave rotor configurations have been developed for different applications. The number and azimuthal location of the wave rotor ports along with heat addition schemes distinguish them for different purposes. As will be shown in the next section, four-port configurations have been used mainly as superchargers for internal combustion engines. Three-port wave rotors have been employed in pressure dividers and pressure equalizers in which the pressures of different fluids are increased or reduced. Two-port, four-port, five-port, and nine-port wave rotors have been investigated for gas turbine engine topping applications, including some with on-board combustion. As an application of current interest, a four-port pressure exchange wave rotor integrated into a gas turbine cycle is briefly discussed below to illustrate wave rotor operation and options.

Figure 3 shows a schematic of a gas turbine cycle using a four-port wave rotor. Following the flow path shown in Fig. 3, air from the compressor enters the wave rotor (state 1) and is further compressed inside the wave rotor channels. After the additional compression of the air in the wave rotor, it discharges into the combustion chamber (state 2). The hot gas leaving the combustion chamber (state 3 ) enters the wave rotor and compresses the air received from the compressor (state 1). To provide the energy transfer to compress the air, the burned gas partially expands in the wave rotor en route to the turbine (state 4). In this configuration, combustion takes place at a higher pressure and temperature than in a conventional gas turbine engine with the same compressor exit state, while being limited to the same turbine inlet temperature. The turbine inlet total pressure is typically $15 \%$ to $20 \%$ higher than pressure of the air delivered by the compressor [10]. This pressure gain is in contrast to the untopped engine where the turbine inlet pressure is always lower than the compressor discharge pressure, due to the pressure loss across the combustion chamber. As a result of the wave rotor pressure gain, more work can be extracted from the turbine, increasing overall engine thermal efficiency and specific work. For instance, a study by RollsRoyce Allison has predicted [11,12] significant performance improvements for both design point and off design operating conditions of the Allison model 250 turboshaft engine topped by a four-port wave rotor, as shown in Fig. 4. It compares specific shaft horsepower and decreases in specific fuel consumption for the topped and baseline engines as a percent improvement for the off design points.

In the above-described wave rotor, both gas and air inlet ports 


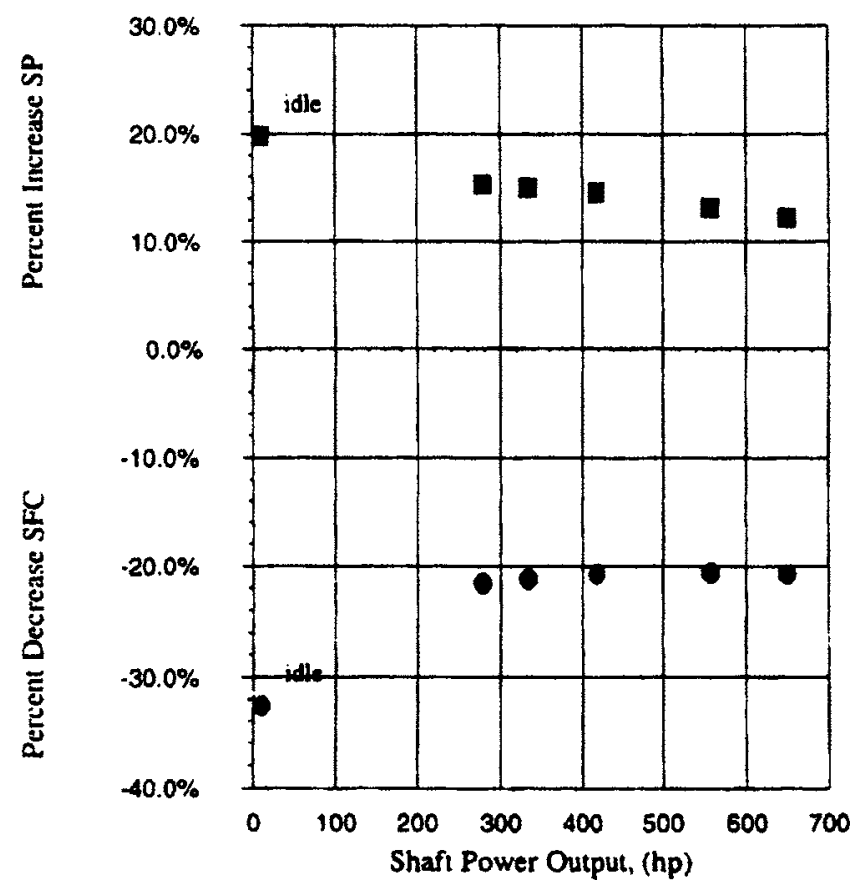

Fig. 4 Comparison of off-design performance to baseline engine performance, taken from Ref. [11]

are located on one side of the rotor while and the outlet ports are located on the other side of the rotor. This configuration is known as the through-flow (TF) wave rotor in the literature. Alternatively, another type of wave rotor has been designed where the fresh air enters and exits at the same end of the rotor (air casing) while the burned gas enters and exits the rotor at the other end (gas casing). This configuration is called the reverse-flow (RF) wave rotor, shown in Fig. 5. These two configurations may provide identical topping and overall performance enhancement, but they differ substantially in their internal processes. In the TF fourport wave rotor, both hot gas and relatively cold air traverse the full length of the rotor, keeping the wall at a relatively uniform intermediate temperature. This self-cooling feature of TF wave rotors has prompted interest in them for gas turbine engine topping applications where gas temperatures are high. The RF configuration does not inherently result in such a self-cooled rotor. The cold air never reaches the other end of the rotor, as seen from Fig. 5. As a result, the air side of the rotor is relatively cool while

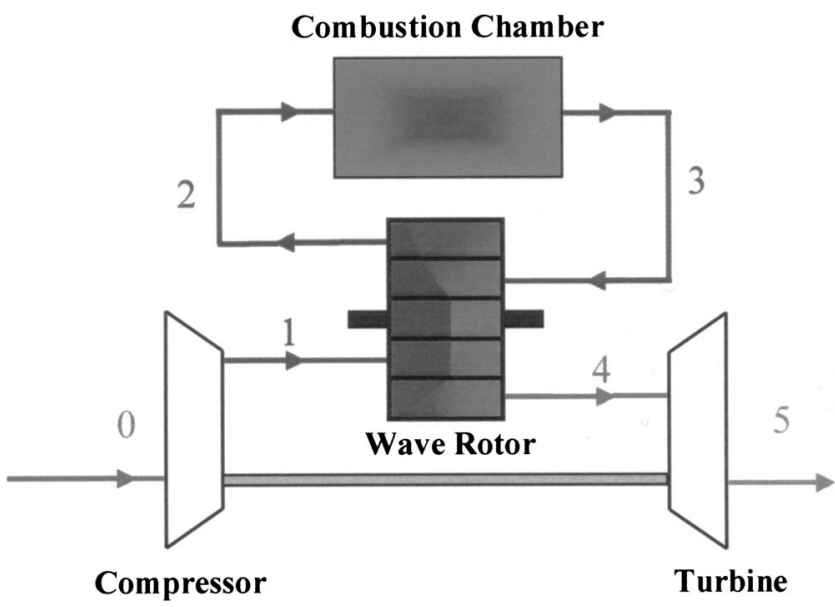

Fig. 5 Schematic of a gas turbine topped by a reverse-flow four-port wave rotor the gas side of the rotor is relatively hot. Thus, the RF configurations have been mostly used in the relatively low-temperature application of engine supercharging although such a configuration for gas turbines has been also investigated [11-14]. The General Electric Company has obtained experimental data on a gas turbine engine enhanced by a RF wave rotor [15].

Inner Workings of a Pressure-Exchanger. Two basic fluidexchange processes usually happen at least once per revolution: the high-pressure (charging) process and the low-pressure (scavenging) process. In the high-pressure process, compression waves transfer the energy directly from a fluid at a higher pressure (driver fluid) to another fluid at a lower pressure (driven fluid). In the low-pressure process, the driver fluid is scavenged from the rotor channels, generating expansion waves that allow ingestion of a fresh low-pressure fluid into the rotor channels.

The wave process occurring inside the wave rotor channels is customarily illustrated by the wave diagram (space-time diagram), where the circular motion of the rotor channels is represented on paper in developed view by a straight translatory motion. It describes the rotor internal operation by tracing the trajectories of the waves and gas interfaces. The wave diagram is very useful for visualizing the wave process occurring inside the channels and also for explaining wave rotor design parameters, i.e., port opening and closing times and their locations. The utility of the wave diagram is analogous to that of a velocity diagram for a conventional turbine or compressor.

Figure 6 taken from a NASA publication [16] presents wave diagrams for the TF (left) and the RF (right) four-port wave rotors, showing the sequence of events occurring during one cycle within the channels moving in the upward direction. The journey of a channel of the wave rotor is periodic. The top of each wave diagram is therefore considered to be looped around and joined to the bottom of the diagram. This presents a fundamental requirement in the simulation and design of wave rotors.

The events occurring in one cycle of a TF four-port wave rotor are now described. As shown in Fig. 6, the process begins in the bottom part of the left wave diagram, where the channel is closed at both ends and contains medium-pressure gas at state V. As the channel gradually opens to the relatively low-pressure outlet port, an expansion fan originates from the leading edge of the outlet port and propagates into the channel, discharging the gas to the turbine. The expansion fan reflects off the left wall and reduces the pressure and temperature inside the channel further. The inlet port at left opens shortly (time $t_{c}$ ), and this depression draws fresh air provided by the compressor into the channel. When the reflected expansion fan reaches the outlet port $\left(t_{a}\right)$, it slows the outflow and reflects back as compression waves, while the outlet port then closes $\left(t_{b}\right)$ and halts the flow inside the channel. The compression waves form a single shock wave as they travel toward the inlet port. As the shock wave reaches the upper corner of the inlet port $\left(t_{d}\right)$, it closes gradually trapping both residual gas (D) and fresh air $(C)$ at state $\mathrm{Q}$.

The above sequence of events is called the low-pressure part of the cycle (scavenging process). Its purpose is to discharge a relatively high-pressure gas into the turbine, partially purge the rotor channels, and ingest fresh low-pressure air received from the compressor. In the high-pressure part of the cycle (charging process) that follows, the rotor channels are first exposed to high-pressure burned gas from the combustion chamber. This hot gas (driver) penetrates the channel triggering a shock wave from the lower corner of the inlet port $\left(t_{e}\right)$. The shock wave runs through the channel and causes an abrupt rise of pressure inside the channel. As the shock wave reaches the right end of the channel, the outlet port opens $\left(t_{g}\right)$ and its lower edge originates a reflected shock wave that propagates back into the channel. The twicecompressed flow comprising both air and once-burned gas behind the reflected shock wave leaves the wave rotor toward the combustion chamber with total pressure sufficient to overcome com- 

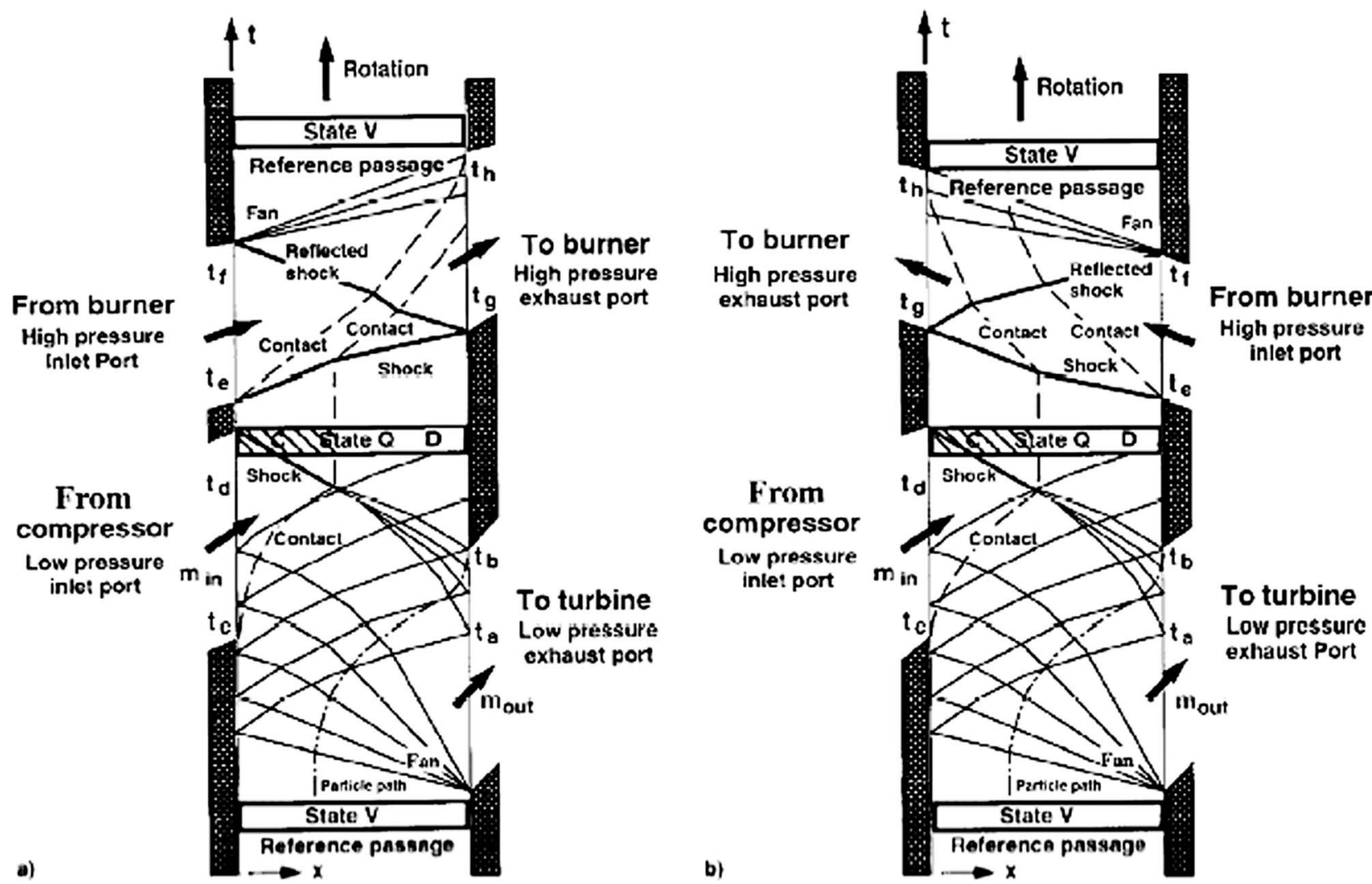

Fig. 6 Wave diagrams for through-flow (left) and reverse-flow (right) four-port wave rotors, taken from Ref. [16]

bustor pressure loss. Detailed fluid flow investigations have suggested that approximately $30 \%$ to $50 \%$ of burned gas is recirculated to the combustion chamber in the TF configuration [17]. A favorite case is considered when the closure of the gas inlet port is timed $\left(t_{f}\right)$ with the arrival of the reflected shock wave. At this moment, an expansion fan originates from the upper corner of the inlet port and brings the channel flow to rest. When the expansion fan reaches the end of the channel, the outlet port closes $\left(t_{h}\right)$ and the flow in the rotor channels stops with the same state $\mathrm{V}$ as at the starting state of the cycle. It is now ready to be discharged into the turbine by the low-pressure process, explained above.

The RF configuration will not be presented in detail, but the right-hand wave diagram of Fig. 6 illustrates most features. The cycle begins with the channel containing both hot gas and a buffer layer separated by a contact surface. The low-pressure scavenging part of the cycle is similar to the TF configuration. The highpressure part has the driver gas inlet on same side as the turbine outlet, allowing only fresh air to be sent to the burner. The buffer gas oscillates back and forth in the channel, never leaving it except by gradual mixing at the contact surfaces. Buffer gas or residual gas can be avoided in pressure-exchangers that do not seek a net pressure gain between the low-pressure ports (such as a supercharger) or have a fifth lower pressure discharge port.

\section{Historical Review}

The following roughly chronological review attempts to summarize the developments in methods and designs of major participating institutions that began before 1985. Many applications were considered, and two or three emerged as commercial or unique solutions, even with simplified methods of predicting complex unsteady flow, perhaps because efficiency was not critical in those applications.
The Early Work (1906-1940). The earliest pressure exchanger proposed by Knauff in 1906 [18] did not employ the action of pressure waves. It consisted of a cellular drum that rotates between two end plates containing several ports through which flows with different pressures enter and leave, exchanging their pressure. Knauff initially described curved rotor blades and inclined stator nozzles to provide output shaft power (pressure exchange engine). Reported by Pearson [19], Knauff in his second 1906 patent [20] and Burghard in 1913 [21] proposed a simpler device in which pressure exchange takes place in long narrow channel configurations (pressure exchanger) known later as the Lebre machine following Lebre's patent in 1928 [22]. Around 1928 , Burghard proposed the utilization of pressure waves [23] in what was termed the "dynamic pressure exchanger" to distinguish it from the previous "static pressure exchangers." Here, the term "dynamic" implies the utilization of pressure waves in both compression and expansion processes taking place inside the rotor channels; hence our preferred term "wave rotor." Limited understanding of unsteady fluid mechanics delayed development of the wave rotor concept [24] until World War II.

The Brown Boveri Comprex® Pressure Wave Supercharger (1940-1989). Brown Boveri Company (BBC), later Asea Brown Boveri $(\mathrm{ABB})$, in Switzerland has a long history in wave rotor technology. As reported by Meyer [25], BBC in the early 1940s designed a wave rotor as a topping stage for a $1640 \mathrm{~kW}(2200 \mathrm{hp})$ British Railways locomotive gas turbine [26-29]. An 80\% power boost and a $25 \%$ efficiency increase was expected, based on the patents of Seippel [30-33]. The wave rotor had 30 channels rotating at $6000 \mathrm{rpm}$, with two opening ports on each side through which air and gas entered and left. It had originally shown a pressure ratio up to $3: 1$ and total efficiency of $69 \%$ in tests during 1941-1943, which correspond to 83\% efficiency for each compression and expansion process [25]. The first wave rotor worked 


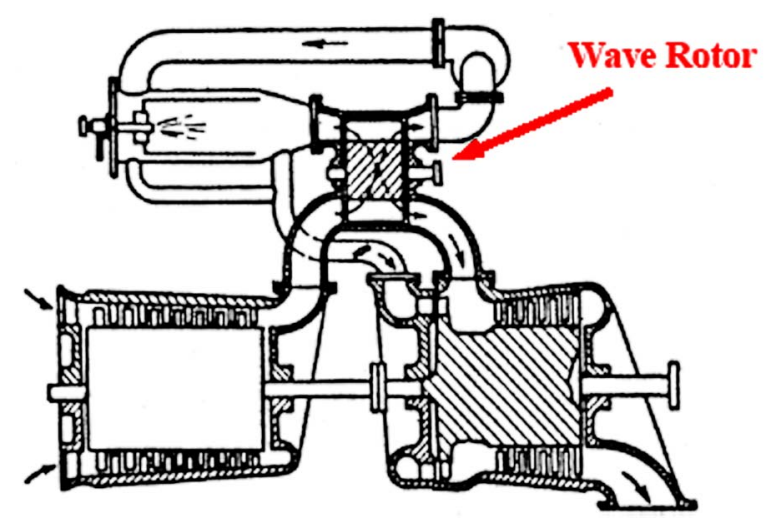

Fig. 7 Wave rotor as a topping stage for the locomotive gas turbine, taken from Ref. [25]

satisfactorily, proving the concept of wave rotor machines. However, its performance, when installed in the engine as shown in Fig. 7, was far from expectations, apparently due to mismatched design and crude integration [28].

Seippel's work, and growing practical knowledge led to the notion of using the wave rotor as a pressure wave supercharger for diesel engines, first by the ITE Circuit Breaker Company in the U.S. [34-36]. In an effort jointly sponsored by the U.S. Bureau of Aeronautics and ITE, supervised by Kantrowitz of Cornell University and Berchtold of ITE, the first units were manufactured and tested on vehicle diesel engines between 1947 and 1955. As a result of this success, a cooperative program with BBC was started in 1955. As a manufacturer of superchargers, BBC pursued the development of pressure-wave superchargers for diesel engines [37], collaborating with the Swiss Federal Institute of Technology (ETH Zurich). While the first prototype was installed in a truck engine in 1971 [38], the supercharging of passenger car diesel engines was started in 1978 [39,40] with a first successful test on an Opel 2.11 diesel engine [40,41]. Given the trade name Comprex ${ }^{\circledR}$, (Fig. 8), its port arrangement indicates the use of two operating cycles per revolution, shortening the rotor length and reducing thermal loads. The main advantage of the Comprex ${ }^{\circledR}$ compared with a conventional turbocharger is its rapid response to driver demand. Light weight and compact size make this device attractive for supercharging small engines (below about $75 \mathrm{~kW}$ or $100 \mathrm{hp)}[42,43]$. By 1987, the first wide application of the Comprex ${ }^{\circledR}$ in passenger cars appeared in the Mazda 626 Capella $[8,44]$, and ultimately in 150,000 Mazda diesel passenger cars [45]. TheComprex ${ }^{\circledR}$ has been also tested successfully on vehicles such as Mercedes-Benz [9], Peugeot and Ferrari [37], and on heavy-duty engines.

The successful development of the Comprex ${ }^{\circledR}$ has been enabled by efforts of other researchers including: Gyarmathy [7], Burri [46], Wunsch [47], Croes [48], Summerauer [49], Kollbrunner [50], Jenny [51], Keller [52], Rebling [53], and Schneider [54], others at BBC [55-68] and elsewhere [69-79]. By the end of the 1980s, the Comprex ${ }^{\circledR}$ activity was transferred to Mazda in Japan $[24,80]$, when researchers at ABB returned to the idea of utilizing wave rotor technology for gas turbine applications $[81,82]$. Nalim has reviewed ABB's recent efforts in developing both pressure-exchange and combustion wave rotors in Ref. $[83,84]$.

During 1990s, a few groups continued research on pressure wave superchargers. Nour Eldin and associates at the University of Wuppertal in Germany developed a numerical method using the theory of characteristics [85-91]. Piechna et al. at the Warsaw University of Technology developed one-dimensional and twodimensional numerical codes [92-98]. Oguri et al. at Sophia University in Japan performed measurements on a gasoline engine supercharged by the pressure wave supercharger [99]. Guzzella et

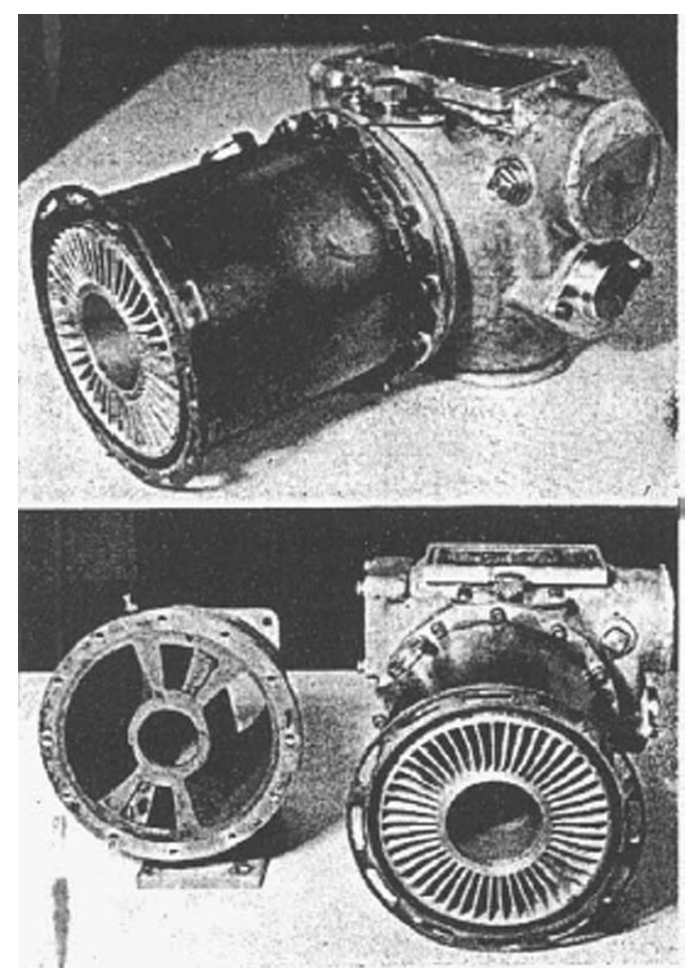

Fig. 8 The Comprex®, taken from Ref. [42]

al. [43,100-104] at ETH in Switzerland developed a controloriented model that describes the engine supercharged by pressure wave devices, with special emphasis on the modeling of transient exhaust gas recirculation. The experimentally validated model has introduced an optimized strategy to operate a supercharged engine with good drivability. Finally, an investigation of Comprex ${ }^{\circledR}$ supercharging on diesel $\mathrm{NO}_{\mathrm{x}}$ emissions has proved fruitful in Turkey [105].

To date, the Comprex ${ }^{\circledR}$ has been the most commercialized of the wave rotor devices. The Comprex ${ }^{\circledR}$ development by $\mathrm{BBC} /$ $\mathrm{ABB}$ also has established fabrication techniques for wave rotors in commercial quantities and produced a mature and reliable machine for internal combustion engine supercharging. For this application, BBC/ABB has solved difficult development challenges in sealing against leakages, noise, and thermal stress. For instance, leakage was kept to an acceptable level by enclosing the rotor in a pressurized casing and using a rotor material with a low thermal expansion coefficient over the operating temperature range [37]. Furthermore, off-design performance over the engine speed range was improved by using pockets in the end plates to control wave reflections [67].

In recent years, Swissauto WENKO AG in Switzerland has developed a more sophisticated version of the pressure wave supercharger [45], known as the Hyprex®, for small gasoline engines. It benefits from the new ETH control features, enabling higher pressure ratios at low engine speeds, further reduced noise levels, and improvement of compression efficiency at medium or high engine speeds. The Hyprex ${ }^{\circledR}$ has been successfully demonstrated with a two-cylinder gasoline engine in a modified Renault Twingo, achieving very low specific fuel consumption and low emissions.

Cornell Aeronautical Laboratory and Cornell University (1948-2001). Inspired by the cooperation with $\mathrm{BBC}$ in the late 1940s, work on unsteady-flow concepts was initiated at Cornell Aeronautical Laboratory (CAL). Among several novel concepts including development of energy exchangers for gas turbine cycles and various stationary power applications [106], the CAL 


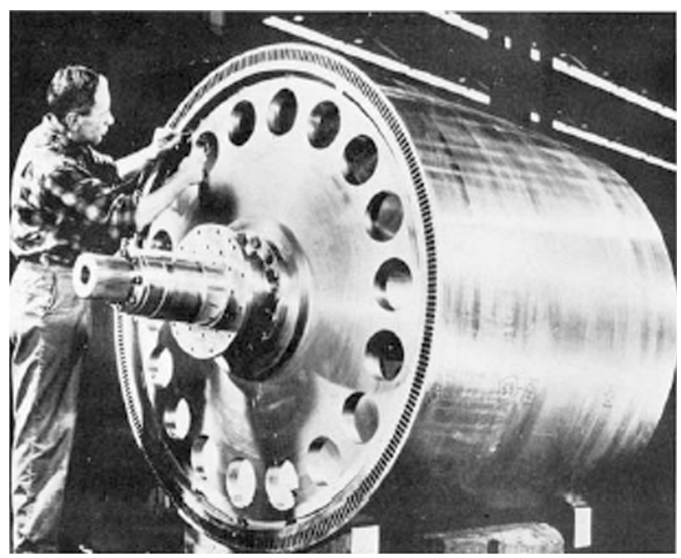

Fig. 9 Photograph of the CAL Wave Supercharger, taken from Ref. [6]

Wave Superheater was built in 1958 and utilized until 1969 [29]. The $2 \mathrm{~m}$ diameter Wave Superheater, photographed in Fig. 9, used heated helium as the low molecular weight driver gas to provide a steady stream of high-enthalpy air for a hypersonic wind tunnel test facility. It compressed and heated air to more than $4000 \mathrm{~K}$ and up to $120 \mathrm{~atm}$ for run times as long as $15 \mathrm{~s}$. The CAL Wave Superheater was a landmark demonstration of the high temperature capabilities of wave rotor devices $[29,106]$.

Around 1985, Resler, a former member of the CAL Wave Superheater team, recommenced wave rotor research at Cornell University. His efforts with his group led to the development of new wave rotor concepts and analytic methods for three-port wave rotor diffusers [107], double-wave rotor cycles [108], five-port wave rotors [108-113], and supersonic combustor aircraft engines using wave rotors [114]. Numerical modeling indicated significant potential for reducing $\mathrm{NO}_{\mathrm{x}}$ in gas turbine engine applications by using a wave rotor for rapid expansion of fuel-rich combustion products. Figure 10 illustrates a double wave rotor in a gas turbine cycle. The idea of using a compound unit consisting of two (or multiple) wave rotors, one supercharging the other, is also reported in an early German patent by Müller in 1954 [115], as stated by Azoury [42].

Power Jets Ltd (1949-1967). In parallel with, but independent of Seippel's efforts in 1940s, Jendrassik, former chief engineer of the Gantz Diesel Engine Company of Budapest, was working on the development of wave rotor machines for gas turbine applications [28,116-118]. He quickly realizes its benefit for aircraft engines, proposing the wave rotor as a high pressure topping stage for early aircraft engines $[119,120]$. His ideas stimulated the Brit-

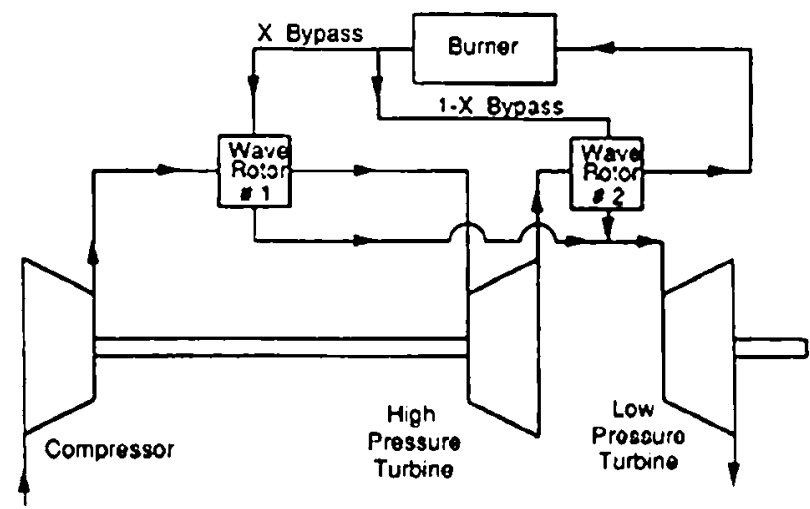

Fig. 10 Schematic of a double wave rotor cycle, taken from Ref. [108]

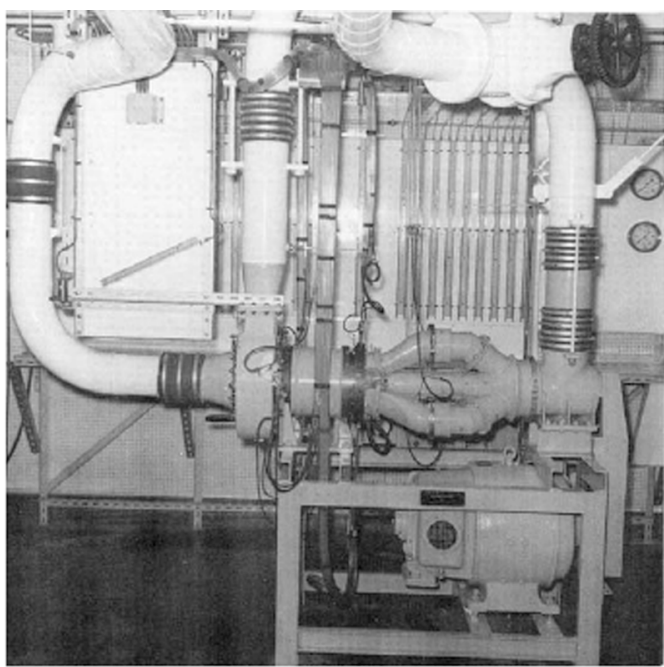

Fig. 11 The experimental divider test rig at Imperial College, taken from Ref. [6]

ish government-controlled Power Jets, Ltd. of jet-engine fame to become active in the wave rotor field in 1949. Initial interest in IC engine supercharging later extended to several other applications including air-cycle refrigerators, gas turbines, pressure equalizers, and dividers $[6,24,28,118]$. For instance, two prototype air-cycle refrigerators using wave rotors were commissioned in gold mines in India and South Africa, with the advantage of low weight and bulk. After Jendrassik's death in 1954, theoretical and experimental work continued at Imperial College, University of London, directed by Spalding and Barnes, and at Ricardo [28,121]. The experimental divider test rig at Imperial College is shown in Fig. 11. Power Jets, Ltd. efforts are detailed in company reports listed in Ref. [6].

Spalding of Imperial College pioneered computational methods for wave rotors considering the effects of heat transfer and friction. It utilized novel features to ensure solutions free from instabilities and physical improbabilities [28]. At the time, manual analysis using characteristics was quite tedious, and could not easily account for loss effects. Based on his numerical model, a computer program was developed by Jonsson [122], and it was successfully applied to pressure exchangers [123-125]. Spalding's students, Azoury [126] and Kentfield [127], continued their efforts on different theoretical aspects of pressure exchangers $[6,24,28,42,118,125,128-131]$ despite the dissolution of Power Jets, Ltd. in 1967 [28].

Ruston-Hornsby Turbine Company: The Pearson Rotor (Mid 1950s-1960). Also in the UK of the mid-1950s, the RustonHornsby Turbine Company, manufacturer of diesel engines and industrial gas turbines, supported the construction and testing of a different kind of wave rotor designed by Pearson $[132,133]$. This unique wave rotor, known as the wave turbine engine or simply the wave engine, has helical channels that change the direction of the gas flows producing shaft work similar to a conventional turbine blade. Pearson designed and tested his wave rotor, shown in Fig. 12, in less than a year. The rotor has a $23 \mathrm{~cm}$ (9 in.) diameter and a $7.6 \mathrm{~cm}$ ( $3 \mathrm{in}$.) length. The engine apparently worked successfully for several hundred hours in a wide range of operating conditions (e.g., 3000-18,000 rpm) without variable porting, and produced up to $26 \mathrm{~kW}(35 \mathrm{hp})$ at its design point with a cycle peak temperature of $1070 \mathrm{~K}$ and a thermal efficiency of around $10 \%$. Better performance seemed possible with improvements to overcome leakage and incomplete scavenging. The design of the engine was based on complex wave diagrams using the method of characteristics that accounted for internal wave reflections, and extra ports and injection nozzles to control and cancel unwanted 

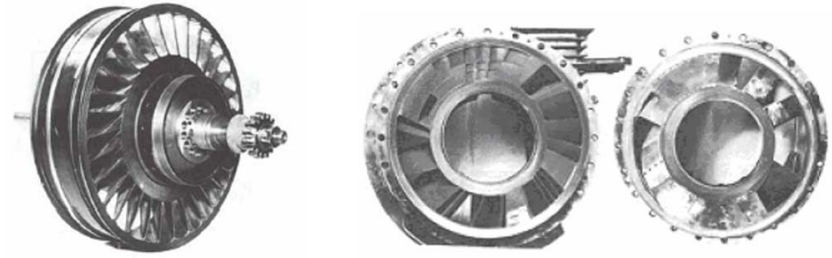

Fig. 12 The Pearson rotor (left) and rear and front stator plates (right), taken from Ref. [132]

reflected waves. The engine had a length of only one-third of its diameter despite having only one cycle per revolution [19]. The sealing and bearings were carefully adapted, considering rotor thermal expansion. Eventually, the engine was wrecked due to over-speeding from an improperly connected fuel line, and the project was tragically canceled when success seemed so close. Despite the technical success achieved, Pearson failed to attract additional funding for this radical idea.

In the early history of wave rotor technology, the Pearson rotor and the Comprex ${ }^{\circledR}$ have performed efficiently over a wide range of operating conditions [28,37,117], demonstrating good offdesign performance, while the Wave Superheater was an equal success at its narrow purpose. Yet, the Pearson rotor is notable for producing a significant power output in addition to being a successful pressure exchanger.

General Electric Company (1956-1963). Contemporaneously, General Electric Company (GE) in the U.S. initiated a wave rotor program in 1956 [15]. The work was motivated by earlier work at NASA Langley initiated by Kantrowitz and continued by Huber [134] during the development of a wave engine in the early $1950 \mathrm{~s}$ and later in 1954-1956 developing pressure gain combustors [15]. GE studied this new configuration of wave rotor in which combustion took place inside the rotor channels (internal combustion wave rotors). Such an arrangement eliminates the external combustion chamber used in the gas turbine cycle, promising significantly lower weight, less ducting, and a compact size. In the period of 1956 to 1959 , the methods used at NASA were analyzed, improved and applied to the design and fabrication of the first internal combustion wave rotor. As reported by Weber [2], the test rig was first tested at the California Advanced Propulsion Systems Operation (CAPSO) of GE. After $20 \mathrm{~s}$ of operation, the rotor seized between the end plates. The test demonstrated the difficulty of clearance control between the end plates and rotor during uneven thermal expansion. While the running clearance between the end plates and rotor must be kept as small as possible, the rotor tends to expand thermally due to hot gases in the rotor, while end plates may warp. This is an especially challenging problem in the design of combustion wave rotors with localized heating and temperature gradients. Henceforth, GE resorted to inferior rubbing seals, and tested only pressure-exchange configurations from 1960 to 1961 [15]. Despite flow leakage, respectable wave rotor overall pressure ratios of 1.2 to 1.3 corresponded to overall temperature ratios of 1.9 to 2.6 were achieved, measured between low-pressure inlet and outlet ports. Meanwhile, a feasibility study was initiated for substituting compressor stages of a T-58 GE-06 engine with a wave rotor. It showed a considerable reduction in overall engine weight and cost, and a $15 \%$ reduction in specific fuel consumption rate, motivating a conceptual design layout of such an advanced engine.

GE also pursued a wave turbine engine. Over the period from 1961 to 1963 , Klapproth and his associates at GE in Ohio fabricated and tested a wave engine using air-gap seals. An ideal wave diagram of this engine is shown in Fig. 13. The engine worked continuously, but it did not produce the anticipated net output power. It is believed that insufficient attention was given to account for internal wave reflections, thus, the flow field calcula-

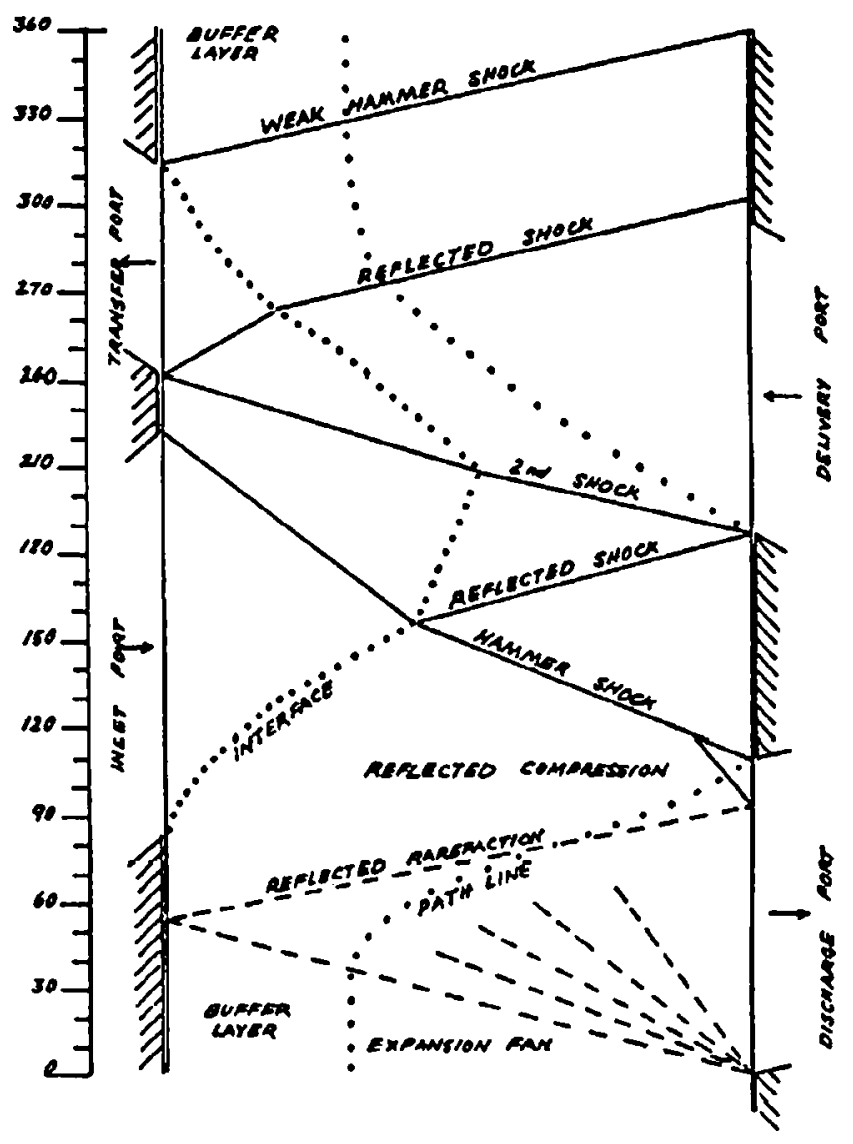

Fig. 13 Ideal wave diagram of the Klapproth rotor, taken from Ref. [15]

tions were inaccurate [37]. Simplifications were unavoidable at that time and generation of wave diagrams by hand required considerable time and effort and small design changes necessitated lengthy recalculations. Although the Klapproth rotor did not produce the expected performance, it clearly demonstrated the possibility of the complete energy conversion within the wave rotor. GE development of the wave rotor was canceled in 1963, with speculated reasons including a shift toward space exploration and rocket propulsion [2], and GE's commitment to pursue large engine development exclusively $[15,134]$.

General Power Corporation (Mid 1960s-1984). In the mid 1960s, General Power Corporation (GPC) started a wave rotor program originally intended for a vehicle engine application [37]. Over a period of about 20 years, GPC spent considerable time and money to successfully design and develop wave rotors. The work was initially supported by Ford Motor Company and later by the Department of Energy (DOE) and the Defense Advanced Research Projects Agency (DARPA). Unfortunately, the GPC work is poorly documented [135]. As stated by Taussig [37,117], while the GPC rotor shared some of the features of the Klapproth and Pearson rotors, it differed in several aspects. Intended to produce reactive shaft power utilizing curved blades, its performance suffered from excessive blade curvatures, lack of control of reflected waves within the device, and the absence of any strong impulsive loading of the rotor from inlet manifolds to produce shaft work. The latter was in contrast with the Pearson rotor that relied heavily on impulsive loading of the rotor blades to achieve power output. Furthermore, the GPC rotor had inadequate off-design performance. Although GPC developed a computer code to obviate manual wave pattern design, accurate calculations were still tedious. Ultimately, Ford withdrew its support from the wave rotor research [136] and GPC discontinued development of the wave 


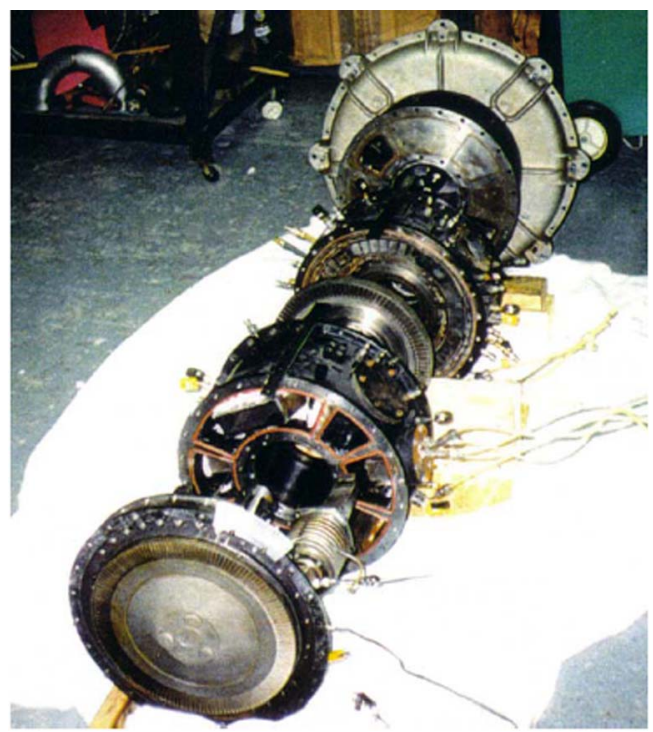

Fig. 14 Disassembled view of the GPC rotor, taken from Ref. [137]

engine in the early 1980s. In 1994, the GPC engine was transferred to the University of Florida for further tests, accurate measurements, and improvements of the seals. Figure 14 shows the disassembled view of the engine. After testing under various operating conditions, major modifications in the starting system, seals and cooling, and rotor design were identified before the engine become a well-characterized experimental testbed [137].

Rolls-Royce (1965-1972). In the mid-1960s, Rolls-Royce (RR) in the UK began numerical and experimental wave rotor research [37]. BBC cooperated with RR in the development of pressureexchange wave rotors as topping spools in gas turbine applications [13], with Berchtold of the ETH and Spalding of Imperial College serving as consultants [24]. Considerable efforts were made to design a wave rotor as a topping stage for a small helicopter engine (Allison Model 250) [138]. The BBC-RR engine utilized a reverse-flow wave rotor incorporated into a single turbine engine. Figure 15 is a rare illustration of the RR reverse-flow wave rotor, taken from a 1965 poster. This was somewhat different from the cycle suggested by Berchtold and Lutz [71] in BBC gas-turbine-topping investigations, which employed a throughflow wave rotor integrated with both low-pressure and high- pressure turbines. BBC's interests in wave rotors at that time were mostly related to development of small gas turbines for passenger cars, beset by poor efficiencies at sizes of $100 \mathrm{~kW}$ and smaller [29]. While the enhanced engine operated nearly as predicated by protracted manual design methods, performance suffered from leakage [37]. Other difficulties related to the start-up, bearing durability, fuel system complications, and control are also reported [10]. The program was abruptly canceled in 1972 amid severe company financial difficulties [13]. As stated by Kentfield [24], contemporaneous rapid progress in turbomachinery technology may have disfavored high-risk projects, both at RR and GE. It is emphasized that published literature is relatively meager on efforts at large corporations like $\mathrm{GE}, \mathrm{ABB}$, and $\mathrm{RR}$, and underlying business strategy is rarely revealed. Internal company records, if they survive, may contain more technical details.

Mathematical Science Northwest Inc. (1978-1985). In the late 1970s, Mathematical Science Northwest Inc. (MSNW, later Spectra Technology Inc.) investigated various applications of wave rotors [29]. Under the sponsorship of DOE and DARPA, they considered wave rotors for a broad range of stationary power systems such as magnetohydrodynamic cycles [37], combined cycles integrated with gasification plants [139], pressurized fluidized bed (PFB) power systems [140], and also propulsion and transportation applications [117]. Significant numerical and experimental efforts included developing a laboratory wave rotor [141-144], shown in Fig. 16. With diameter of $45 \mathrm{~cm}$, it consists of 100 channels each with a $40 \mathrm{~cm}$ length. It is a four-port wave rotor with two additional small ports provided to cancel pressure waves at critical rotor locations providing more uniform port flows and a higher transfer efficiency [144]. Besides successful tests using several configurations (clearance variations, port sizes, etc.) and various operating conditions, experiments were designed to verify the scaling laws for predicting the performance of larger machines [139]. The MSNW wave rotor was initially designed based on the method of characteristics, but a one-dimensional unsteady computer code (the FLOW code) was later used for optimization [117]. Modifications led to very good agreement between the numerical and experimental results in a wide range of operating conditions. The FLOW code, which was developed specifically for both pure pressure exchanger wave rotor and wave engine analyses, used the flux-corrected transport algorithm solving Euler equations accounting for heat transfer, viscosity, gradual port opening, and flow leakage. The sensitivity of wave rotor performance to tip speed, port placement and size, inlet and outlet flow conditions, channel geometry, number of channels, leakage, and heat transfer was analyzed for both on-design and off-design

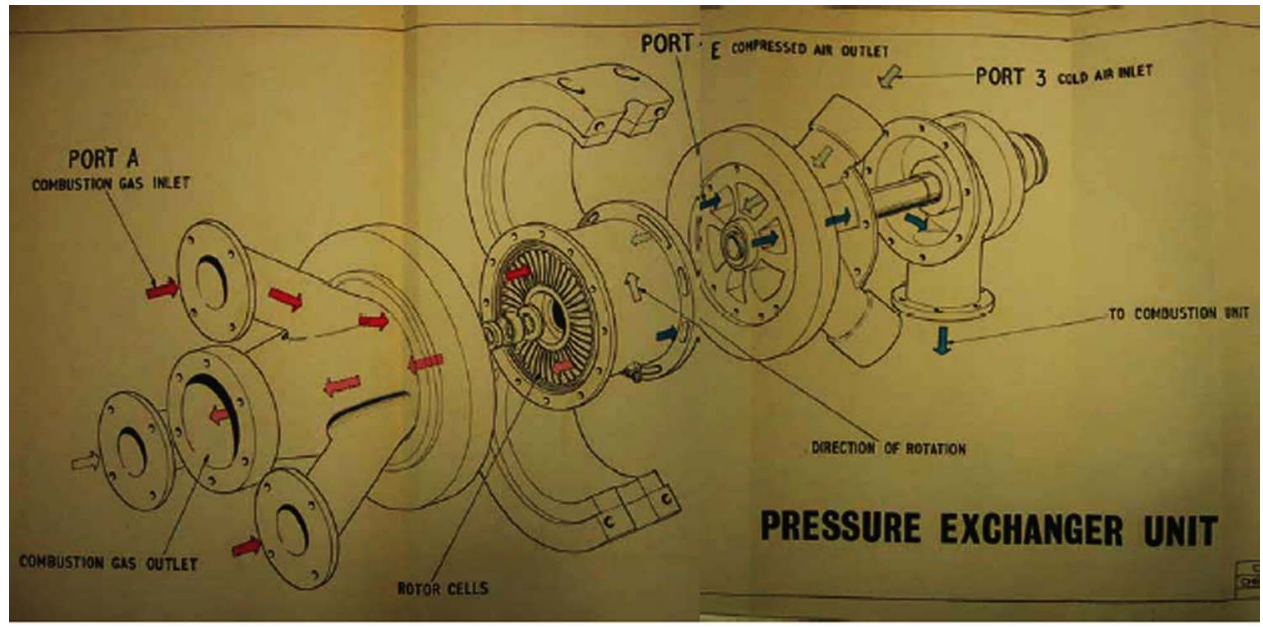

Fig. 15 Reverse-flow wave rotor of Rolls-Royce 


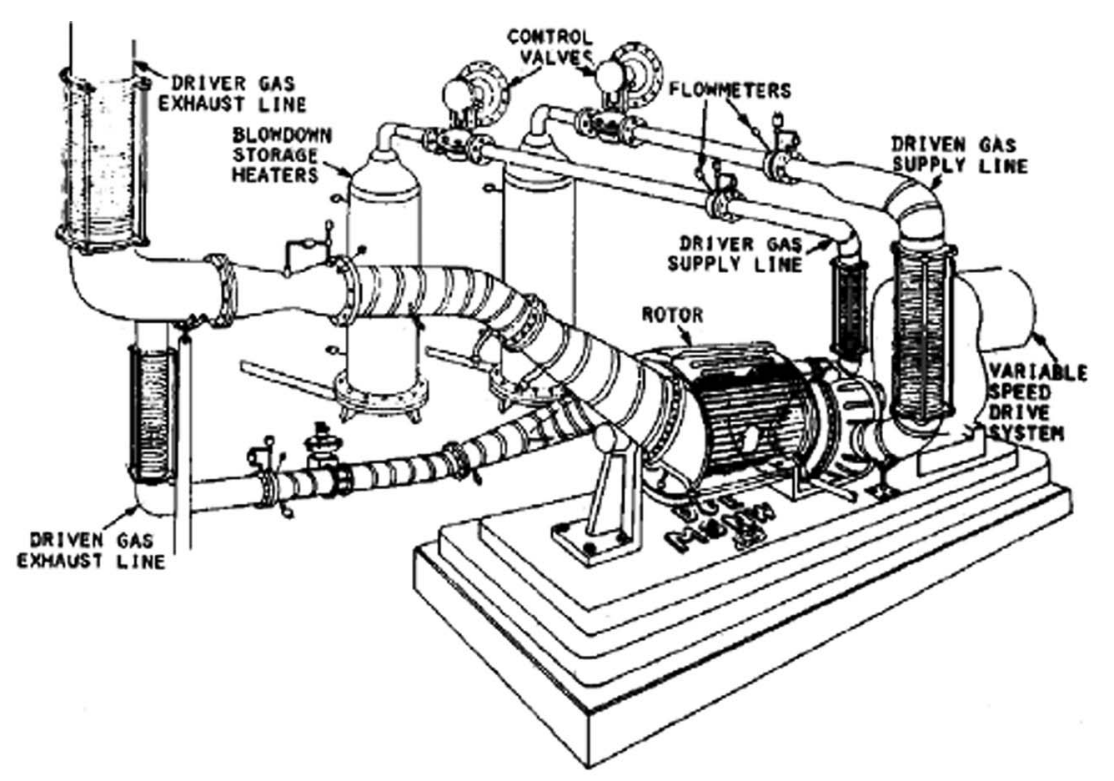

Fig. 16 Schematic of the MSNW wave rotor experimental setup, taken from Ref. [29]

conditions. It was concluded that heat transfer losses were negligible, and leakage was recognized as a key problem for efficient wave rotor operation. Numerical work was reported for a nineport wave rotor concept to resolve the problem of nonuniform port flows and poor scavenging.

MSNW also produced preliminary wave rotor designs for a small turbofan engine generating $600 \mathrm{lb}$ thrust at sea level condition $[117,145]$, illustrated in Fig. 17. Performance calculations for both on-design and off-design flight conditions using a cycle performance code and the FLOW code simulation predicted significant performance improvements of such an enhanced engine. No new material development for such combined engines was required. The wave rotor activity at MSNW was discontinued in the mid 1980s, for reasons not reported.

Naval Postgraduate School (1981-1986). In 1981, the Office of Naval Research (ONR) agreed to monitor a joint DARPA/ONR program to evaluate the wave rotor concept and its potential application in propulsion systems [134]. Following this decision, the Turbopropulsion Laboratory (TPL) at Naval Postgraduate School (NPS), directed by Shreeve, started an extensive numerical and analytical wave rotor program. To support the accuracy of the computational results, the wave rotor apparatus formerly used by Klapproth at GE was transferred to TPL and some preliminary tests were carried out. It is reported that the rotor produced some shaft work running at approximately 5000 to $6000 \mathrm{rpm}$ [146]. No further experimental details are reported.

For numerical simulations, two different approaches to the solution of the unsteady Euler equations were examined in the overall program. First, Eidelman developed a two-dimensional code based on the Godunov method to analyze the flow in wave rotor channels [147-149]. Unlike contemporary one-dimensional approaches [150], the two-dimensional code showed the effect of gradual opening of the channels. The main conclusion of these studies is that if the channels are straight, the flow remains nearly one-dimensional, which in turn leads to minimal mixing losses caused by rotational flow in the channels [151]. However, when the channel of the wave rotor is curved, even an instantaneous opening of the channel does not lead to the development of a one-dimensional flow pattern with small losses. For faster computations, a one-dimensional, first-order time-accurate code was in-

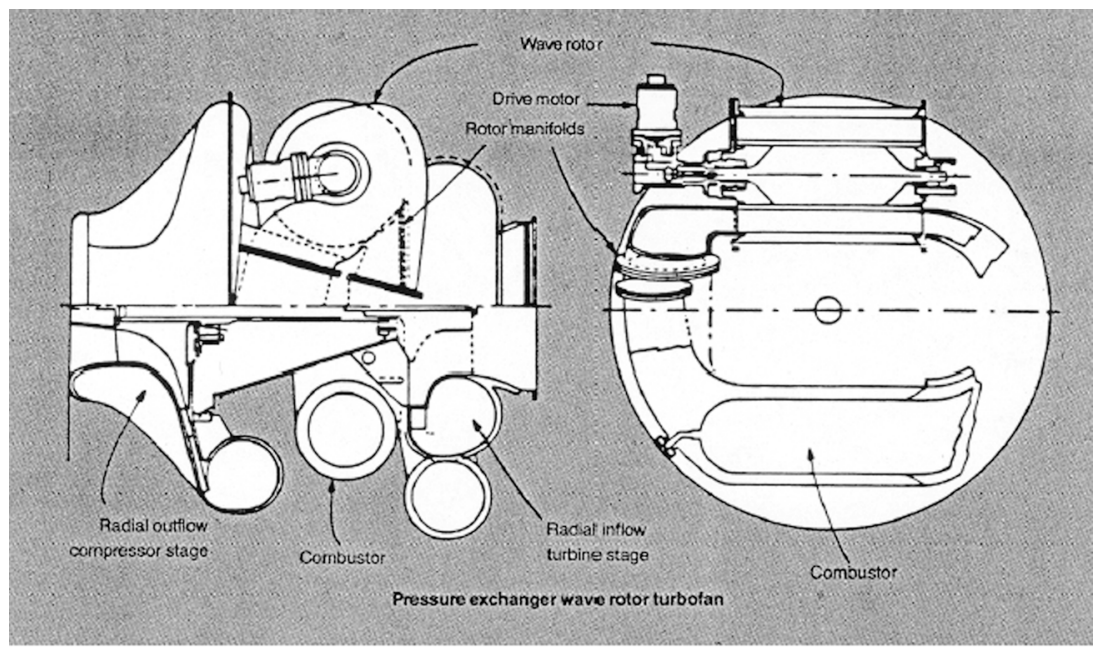

Fig. 17 Conceptual design of a turbofan engine incorporating a wave rotor, taken from Ref. [145] 
troduced by Mathur based on the random choice method for solving the Euler equations $[152,153]$. The unconditionally stable code, called WRCOMP (wave rotor component), calculated the unsteady-flow process inside the wave rotor, inlet and outlet opening times, and other useful design parameters required for a preliminary design. The outputs from WRCOMP were used in a second program, called ENGINE, for turbofan jet engine performance calculations [154-156], and predicted significant performance improvement of a turbofan engine. Some improvements to WRCOMP code were begun $[157,158]$, but the wave rotor research was terminated around 1986. NPS also sponsored the most comprehensive wave rotor conference in 1985 [159], which reviewed much of the history to that point.

\section{Recent Research and Development}

Since the 1985 wave rotor workshop, there has been significant progress in wave rotor research, supported by improved methods that include powerful computational capabilities allowing accurate simulation of the flow field inside the wave rotor, and modern experimental measurement and diagnostic techniques. Improvements in aerodynamic design, sealing technologies, and thermal control methods have been sought for applications that demand highly efficient performance. Numerous studies of the performance benefits of wave rotor topped gas turbines underline the motivation to obtain a quantum improvement in performance over conventional engines. Use of a wave rotor for confined combustion received renewed interest in Switzerland and the U.S., and was further stimulated by developments in related processes of pulsed detonation engines. The following recent and ongoing efforts indicate that a modern computational methods and experimental tools are allowing improved understanding, and more realism in integration with conventional machines.

NASA Glenn Research Center (1988-Present). Since the late 1980s, a sustained research program at NASA Lewis (now Glenn) Research Center (GRC), collaborating with the U.S. Army Research Laboratory (ARL) and Rolls-Royce Allison has aimed to develop and demonstrate the benefits of wave rotor technology for future aircraft propulsion systems [10]. In 1993, using a thermodynamic approach to calculate the thermal efficiency and specific power, Wilson and Paxson [160] published a feasibility study for topping jet engines with wave rotors. Applied to the case of an aircraft flying at Mach 0.8 , they have shown that a wave-rotortopped engine may gain $1-2 \%$ in efficiency and $10-16 \%$ in specific power compared to a simple jet engine with the same overall pressure ratio and turbine inlet temperature. In 1995, Welch et al. [17] predicted a $19-21 \%$ increase in specific power and a $16-17 \%$ decrease in specific fuel consumption compared with the baseline engines for small (300 to $500 \mathrm{~kW}$ ) and intermediate (2000 to $3000 \mathrm{~kW}$ ) wave-rotor-enhanced turboshaft engines. A wave-rotorenhanced large turbofan engine, equal in thrust to the baseline engine, showed a $6-7 \%$ reduction in thrust specific fuel consumption. Welch has also studied the possibility of curving the channels to create a wave turbine $[161,162]$.

Early in the program, Paxson developed a quasi-onedimensional gasdynamic model and a computational code to calculate design geometry and off-design wave rotor performance $[163,164]$. The code uses an explicit, second order, Lax-Wendroff type TVD scheme based on the method of Roe to solve the unsteady-flow field in an axial passage for time-varying inlet and outlet port conditions. It employs simplified models to account for losses due to gradual passage opening and closing, viscous and heat transfer effects, leakage, flow incidence mismatch, and nonuniform port flow field mixing. In order to verify wave rotor flow predictions and to assess the effects of various loss mechanisms [165], a three-port wave-divider machine was constructed and tested $[166-168]$ in a new wave rotor laboratory facility at GRC. Concurrently, the nonideal behavior and losses due to multidimensional effects were studied by Welch [169-171] and Laro-

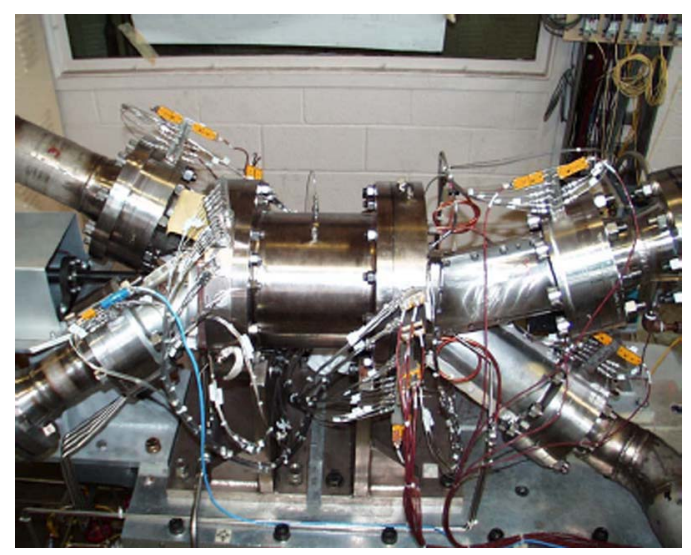

Fig. 18 NASA four-port wave rotor

siliere [172,173]. Welch has also established macroscopic and passage-averaged models to estimate the performance enhancements of wave rotors $[16,174]$. Based on experimental data, Paxson further improved the one-dimensional model $[165,175,176]$ and used it to evaluate dynamic behavior, startup transients, and channel area variation [177-179]. This model was then used as a preliminary design tool to evaluate and optimize a four-port wave rotor cycle for gas turbine topping [180]. A through-flow cycle was chosen based on several perceived merits, including relatively uniform rotor temperature, and the feasibility of integration with gas turbomachinery. As a result of these studies, a new four-port wave rotor was designed and built [181] to test the performance of this concept under scaled laboratory conditions. A photograph of the NASA four-port wave rotor is shown in Fig. 18. However, a study by Rolls-Royce Allison [11] discussed further below indicated that thermal loads on the rotor and ducting predicted for the NASA wave rotor cycle in real engine conditions may be difficult to manage. In response, Nalim and Paxson $[182,183]$ proposed an alternative cycle with a combustor bypass significantly lowering thermal loads.

In 1995, Nalim at NASA published a feasibility assessment of combustion in the channels of a wave rotor, for use as a pressuregain combustor [184]. Combustion prediction capability was added to the wave rotor code by Nalim and Paxson [185], enabling the exploration of wave cycles involving both detonation and deflagration modes of combustion. A single reaction progress variable was used for uniform mixtures, while multiple species were represented for stratified mixtures in deflagration modes. A single-step mixing controlled reaction was combined with a simple eddy diffusivity model, ignition-temperature kinetics, and a simple total-energy based flammability limit [186]. The performance of detonative and deflagrative cycles was studied by combined computational fluid dynamics and system simulation. It was determined that deflagrative combustion with longitudinal fuel stratification could be accomplished over a reasonable time in wave rotors. The code's one-dimensional detonation prediction capability later became widely useful for study of pulse detonation engines (PDE).

Recent NASA work focused on experimental tests with special attention to sealing technology [187-189], identified as a critical challenge in high-pressure wave rotor design. The worldwide resurgence of interest in PDE technology in the 1990s has piqued interest and found synergies in wave rotor research, especially the combustion wave rotor research at NASA.

Asea Brown Boveri (1989-1994). Following the successful results of the Comprex ${ }^{\circledR}$ supercharger by BBC, in 1989 BBC/ABB commenced a three-phase research project to employ the wave rotor concept for gas turbine engines. The first phase of the project was aimed at testing a pressure-exchange wave rotor with external 

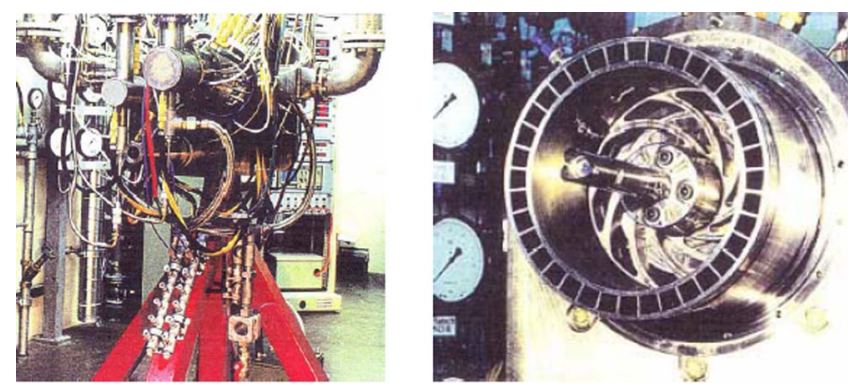

Fig. 19 ABB test rig (left) and cross section of the rotor channels (right), taken from Ref. [190]

combustion. The demonstrator engine produced $17 \%$ and $25 \%$ increases in efficiency and specific power, respectively, compared with the baseline engine [81]. The obtained significant performance improvement encouraged ABB to investigate the possibility of manufacturing an integrated combustion wave rotor, started in 1991. To explore fundamental parameters of such a constantvolume combustion device, a rotary-valved single-channel wave rotor was built and tested [82]. Using preheated and precompressed air-propane as the working fluid, combustion measurements revealed low NOx values, down to $20 \mathrm{ppm}$, at the exhaust gas due to the short residence time (1-6 ms).

After successful operation of the fixed single channel device, the design of an on combustion rotating wave rotor with 36 channels was started in 1992 [82,190]. Figure 19 shows a picture of the test rig and the cross section of the rotor channels including the rotating shaft. The inner diameter of the rotor was $20 \mathrm{~cm}$ and each channel had $16.5 \mathrm{~cm}$ length and $15 \times 15 \mathrm{~mm}$ cross section. The rotor was driven by an electric motor capable of up to 5000 revolutions per minute. Both in the single-tube and 36-channel wave rot engine, spark plug and hot gas-injection self-sustaining ignition methods were utilized. Self-sustaining ignition was accomplished by employing jet injection of already-burned gas from a neighboring channel as suggested by Keller [191]. Such an ignition technique, which makes the combustion process essentially continuous without need for pulsed methods with ignition delays, has a good potential to enhance ignition reliability and burning rate, and can lead to a self-sustaining engine [192-194]. During the tests, various fuels were tried and fuel mixture was stratified via four injection nozzles. Operating in two cycles per revolution, the engine had high-pressure and low-pressure outflows per cycle, enabling it to scavenge the exhaust gas in one cycle.

The prototype engine operated successfully until the project was concluded in 1994, due to market concerns. During its operation, a number of problems were revealed and reported. They included (i) inhomogeneous mixture in the cell, resulting in a slow diffusion flame, (ii) maximum pressure reached was 9 bar, and leakage caused premature ignition and misfiring at higher chamber pressures, (iii) thermal stresses on the ignition ring, (iv) cantilever single bearing rotor support was inadequate, and (v) electromechanical device for controlling leakage gap turned out to be very complicated and sensitive. Major remedies recommended to make the system better include (a) lead away duct for leakage gas removal, (b) rotor cooling by air, (c) two-sided rotor support, and (d) mechanical control for thermal expansion.

Rolls-Royce Allison (1990-Present). Allison Engine Company (later Rolls Royce Allison, and now Rolls Royce) was a close partner in the NASA program. In 1996, Snyder and Fish [11,12] of Allison Engine Company evaluated the Allison 250 turboshaft engine as a potential platform for a wave rotor demonstration, predicting an $18-20 \%$ increase in specific power and a $15-22 \%$ decrease in specific fuel consumption. They used a detailed map of the wave rotor cycle performance accomplished by Wilson and Paxson $[10,160,180]$. Allison has also studied transition duct de- signs for integration with turbomachinery [195,196]. This was later followed by investigations of pulse detonation wave rotors in the newly formed Allison Advanced Development Company (now Rolls-Royce "LibertyWorks"). A novel four-port device was proposed [197,198] for supersonic turbofan engines [199], and was investigated in collaboration with Nalim at Indiana University Purdue University Indianapolis (IUPUI) as discussed later.

University of Florida (1992-1998). Motivated by NASA wave rotor successes, Lear et al. at the University of Florida initiated analytical and numerical methods to investigate different configurations of wave rotors. His team developed an unsteady twodimensional numerical code using a direct boundary value method for the Euler equations to analyze the flow in wave rotors and their adjoining ducts, treating the straight or curved channel walls as constraints imposed via a body force term [200,201]. The code was used to simulate the flow fields of the three-port NASA wave rotor and the GPC wave engine [137]. They also introduced a preliminary design method for selecting the wave engine inflow and outflow blade angles, and an analytical thermodynamic model [202], which predicted potential increase in specific power of $69 \%$ and a $6.8 \%$ increase in thermal efficiency over a conventional gas turbine. A parametric study of gradual opening effects on wave rotor compression processes is also reported [203].

ONERA in France (1995-1999). Fatsis and Ribaud at the French National Aerospace Research Establishment (ONERA) have investigated wave rotor enhancement of gas turbines in auxiliary power units, turboshaft, turbojet, and turbofan engines $[14,204]$, accounting for compression and expansion efficiency, as well as mixing and pressure losses in the ducting. Their results show the largest gains for engines with a low compressor pressure ratio and high turbine inlet temperature, such as turboshaft engines and auxiliary power units, consistent with NASA GRC studies [205]. They have also developed a one-dimensional numerical code based on an approximate Riemann solver taking into account viscous, thermal, and leakage losses [14,206], and applied it to three-port, through-flow, and reverse-flow configurations.

\section{Recent Academic Work}

Besides ongoing research mainly at NASA, Allison Advanced Development Company (AADC), and ETH Zurich, a few universities have been conducting wave rotor research. To the knowledge of the authors, the universities listed below are active in this field.

Purdue School of Engineering and Technology, IUPUI (1997-Present). Recent research at Indiana University Purdue University Indianapolis (IUPUI) by Nalim and coworkers has focused on the combustion wave rotor concept $[83,84]$, following initial work at NASA described before. Deflagrative combustion with longitudinal fuel stratification has yielded a wave rotor geometry competitive with pressure-exchanger designs using a separate combustor [186]. Nalim has highlighted the importance of leakage flow temperature and thermal management of end-wall temperatures illustrating the impact of the hot ignition gas and the cold buffer zones on the end walls. This is consistent with the major challenges revealed by the ABB experiment [82]. Radial stratification [207] using a pre-combustion partition has been proposed to introduce a relatively cooler buffer zone close to the leakage gaps, reducing hot gas or fuel leakage to the rotor cavity. Figure 20 is a contour plot of the temperature contour from a simulation of deflagrative combustion in a stoichiometric partition region propagating into a leaner mixture in the main chamber. Above and below the partitions, there is no fuel, and gas may leak out or in without danger of overheating or pre-ignition. These thermal management approaches are possible utilizing extensive cycle design studies and analysis, and seek to alleviate the challenges previously recognized by $\mathrm{ABB}$ and NASA. This technique also helps burn leaner mixtures, resulting in reduced $\mathrm{NO}_{\mathrm{x}}$ emis- 


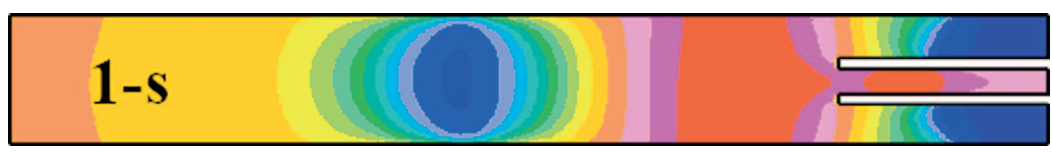

Fig. 20 Temperature distribution of partition exit flow, taken from Ref. [208]

sions, similar to other pilot combustion or lean-burn techniques in conventional engines [208]. For this approach, radial leakage flows [209] and different combustion models [210] have been studied in detail. These ideas have not yet been tested experimentally.

Detonative combustion cycles for propulsion engines have been also studied $[211,212]$. Interest in detonative combustion initially focused on pulsed detonation engines (PDEs) has evolved to the consideration of the wave rotor as an effective implementation of the concept [213], as the wave rotor provides automatic highspeed valving, nearly steady inflow and outflow, and the use of one or few steady ignition devices for multiple tubes. However, detonative combustion is fundamentally restricted to highly energetic mixtures and sufficiently large passage widths, and generates strong pressure waves. This results in the outflow being highly nonuniform in pressure, velocity, and possibly temperature. To better utilize the output of a wave rotor PDE, it has been proposed to add an ejector element to the wave rotor [214,215]. The rotary wave ejector admits bypass air after the detonation tubes to transfer energy and momentum. Numerical simulations using a quasione-dimensional code, modified to account for radial-type bypass flows, have shown that the specific impulse at static thrust conditions can be doubled, after accounting for flow-turning and shock losses, comparing with an equivalently loss-free PDE cycle. A sample wave diagram and a schematic sketch are given in Fig. 21, where the cold ejector gas flow is clearly distinguishable.

IUPUI has also investigated [198] the four-port detonation wave rotor proposed by AADC (now Rolls-Royce "LibertyWorks") [197], in which a recirculation duct allows air that is compressed by the shock of a detonation wave to be reinjected with fuel. Air-buffer regions both between the fuel/air-combusted gas interface and at the exit end plate are inherent in the cycle design, allowing self-cooling of the walls. The inflow and outflow of this engine concept is designed to be nearly uniform and acceptable to modern turbines, compared to conventional rotary detonation cycles, as shown in Fig. 22.

A computational and experimental program is currently being conducted at IUPUI in collaboration with Rolls-Royce to investigate the combustion process and performance of a wave rotor with detonative and near-detonative internal combustion. A preliminary design method based on a sequence of computational models has been developed to design wave processes for testing in an experimental test rig [216].

University of Tokyo (2000-Present). Nagashima et al. have developed one-dimensional [217] and two-dimensional [218] numerical codes to simulate the flow fields inside through-flow fourport wave rotors, including the effects of passage-to-passage leakage. The codes have been validated with experimental data obtained by a single-channel wave rotor experiment. The test rig, shown in Fig. 23, consists of a stationary single tube, and two rotating plates connected to a shaft driven by an electric motor. This group has also explored the idea of using wave rotors for ultra-micro gas turbines manufactured using microfabrication technology $[219,220]$.

Michigan State University (2002-Present). The MSU wave rotor group has initiated studies to evaluate wave rotor technology benefits for several thermal cycle applications. Two unrecuperated microturbines (30 and $60 \mathrm{~kW}$ ) implementing various wave-rotortopping cycles were predicted to have overall thermal efficiency and specific work enhancement up to $34 \%$ for the smaller engine and $25 \%$ for the larger engine, using a four-port wave rotor with a compression ratio of 1.8 [221,222]. A similar approach has predicted an improvement up to $15 \%$ of overall efficiency and specific thrust in a turbojet engine using the wave-rotor-topping cycle of $30 \mathrm{~kW}$ microturbine [223]. Furthermore, multi-parametric performance maps for different wave rotor implementations have been generated specifying optimum operating points for both untopped baseline and topped engines [224]. Using predicted performance results, an analytical preliminary design procedure was developed for the critical high-pressure phase of four-port wave rotors $[225,226]$. To validate and support the accuracy of the analytical results, comparisons with numerical results of a test case was performed [227].

Recently, a unique application of wave rotors in refrigeration cycles using water (R718) as a refrigerant has also been studied [228-231]. The wave-rotor implementation can increase efficiency and reduce the size and cost of R718 units. A three-port wave rotor has been introduced as a condensing wave rotor that employs pressurized water to pressurize, desuperheat, and condense the refrigerant vapor-all in one dynamic process. In addition to the possibility of an additional rise of the vapor pressure,

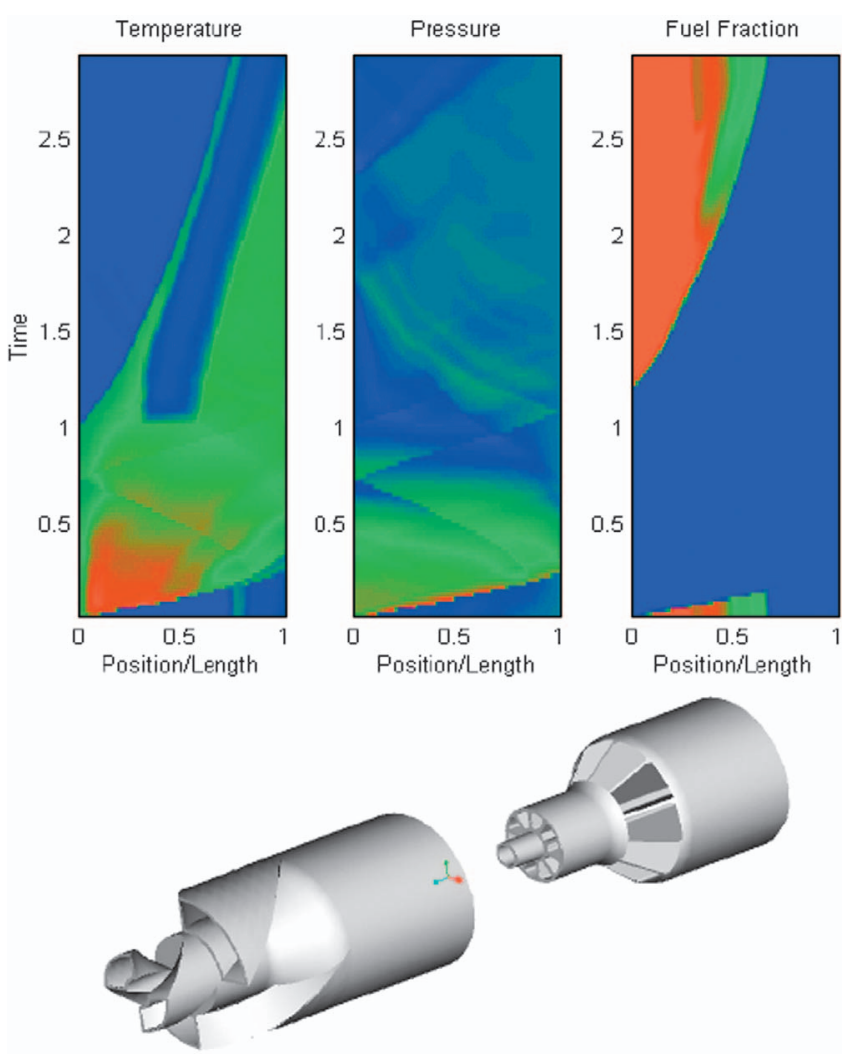

Fig. 21 Rotary Wave Ejector Pulse Detonation Engine, taken from Ref. [214] 

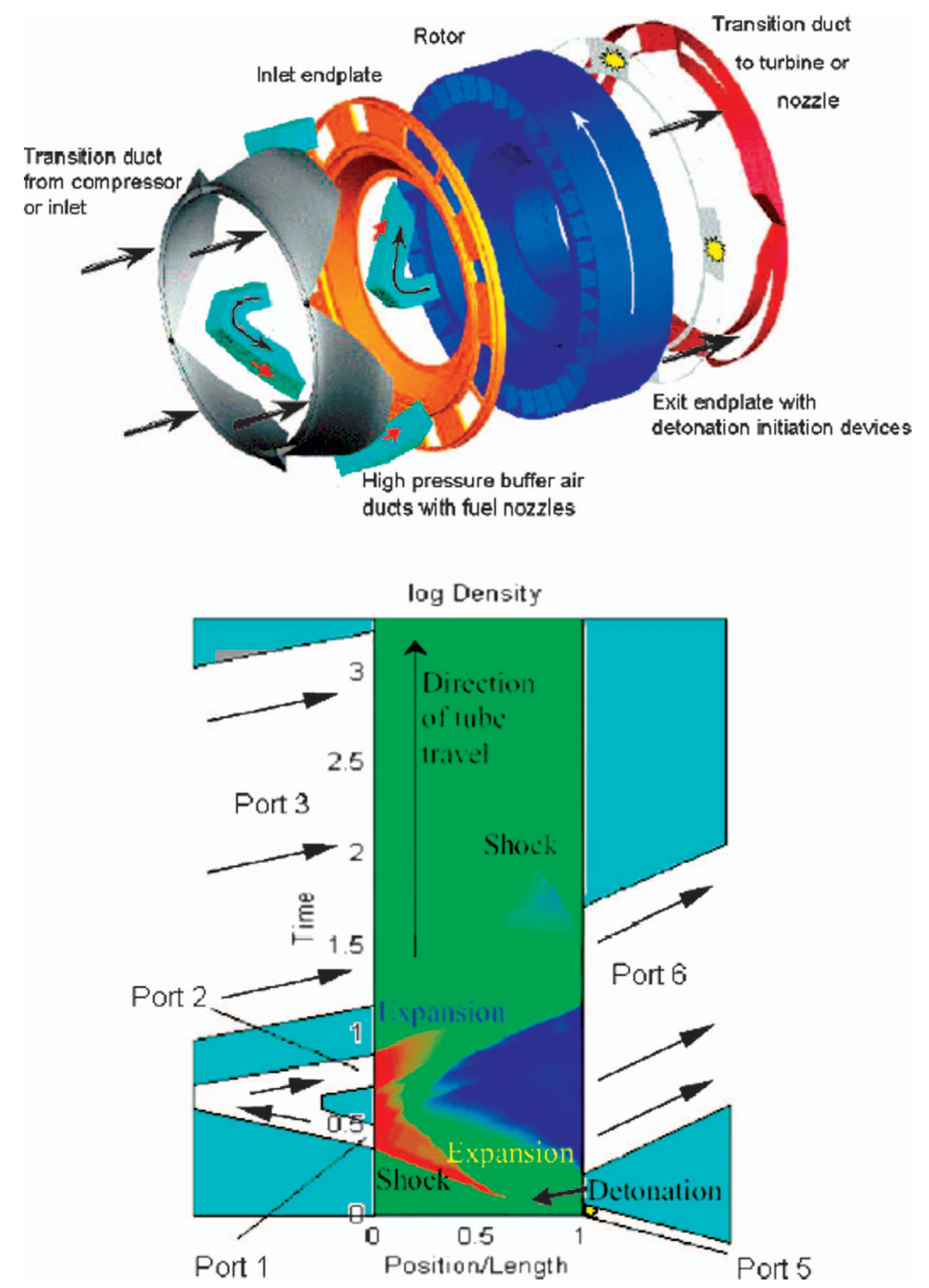

Fig. 22 Wave Rotor Pulse Detonation Engine, the "CVC" Engine, taken from Ref. [198]

the condensing wave rotor eliminates the need of a bulky condenser because full condensation occurs inside the rotor channels. Furthermore, adding a condensing wave rotor to a water refrigeration cycle allows for a lower pressure ratio of the compressor, which is crucial for R718 chiller technology. Figure 24 shows a schematic of a R718 cycle using a three-port condensing wave rotor.

Investigations of the feasibility and potential of integrating wave rotors in microfabricated gas turbines are also being pursued at MSU [3,232-235]. Ultra-micro gas turbines ( $\mu \mathrm{GT})$ have shown difficulties in obtaining high overall thermal efficiency and output power. Utilizing wave rotor technology was suggested to improve the performance of $\mathrm{U} \mu \mathrm{GT}$. The wave rotor can enhance both the overall thermal efficiency and specific work output, based on MSU studies that show an efficiency of the compression between $70 \%$ and $80 \%$ can be achieved in an ultra-micro wave rotor. Several different conceptual designs for a four-port wave rotor integrated into a baseline $\mathrm{U} \mu \mathrm{GT}$ are reported [232]. Additionally, in a collaboration between MSU and Warsaw University of Technology in Poland, the concept of radial-flow wave rotor configuration for various gas turbines applications with an emphasize on
$\mathrm{U} \mu \mathrm{GT}$ was introduced [234,235]. Figure 25 is an example of an ultra-micro wave rotor playing simultaneously the role of compressor, turbine and electric generator.

MSU and Warsaw University of Technology have also employed the commercial software FLUENT [236-239] to investigate detailed gasdynamic phenomena inside axial and radial wave rotors. FLUENT is capable of accounting for the major losses oc-
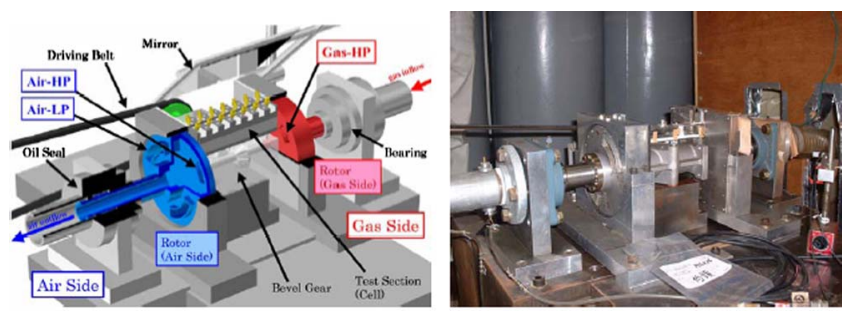

Fig. 23 University of Tokyo single-channel test rig, taken from Ref. [218] and a personal visit 


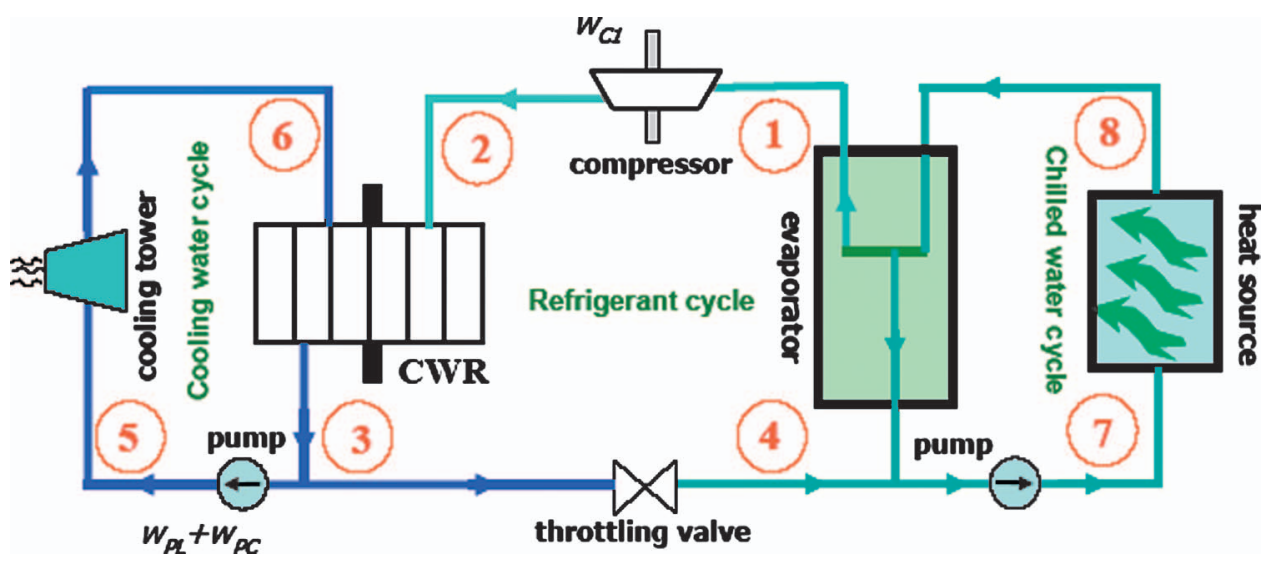

Fig. 24 Schematic of the thermodynamic model of a R718 unit enhanced by a three-port condensing wave rotor (CWR), taken from Ref. [230]

curred inside wave rotor channels including viscous and heat transfer losses, flow leakage between rotating channels, and gradual opening/closing of channels to the ports, along with other multi-dimensional features. To validate the computational results, MSU has built a wave rotor rig [240]. Piechna at Warsaw University of Technology also proposed integration of a pressure exchanger with the internal combustion wave rotor, creating an autonomous pressure wave compressor [241].

\section{Summary}

The goal of this review was to report the continued interest in wave rotor technology and its wide variety of applications. While involved researchers may have state-of-the-art and historical knowledge of this technology, it has not reached wider audiences, limiting the opportunity for meeting needs in new fields. The falling cost of computer simulation bodes well for the study of complex non-steady flow that cannot be characterized in essence by a simple global performance equation. Naturally, recent efforts were discussed in more detail as fuel costs, new research data and methods, and technology innovations have provided fresh impetus to consider the unique capabilities of wave rotor devices. Figure
26 summarizes the known history of the wave rotor research reviewed here, arranged broadly by geography. It appears that interest in gas turbine topping cycles and IC engine supercharging continues, but new opportunities appear, especially for small-scale wave machines and combustion devices that may substantially surpass conventional concepts. Continued research on sealing and thermal expansion control are needed to solve these persistent challenges, but it is important to understand and learn from the approaches of earlier workers.

\section{Acknowledgment}

The authors gratefully acknowledge several colleagues who provided valuable historical information, comments, and suggestions through personal communications. Special recognition is given to L. Guzzella at ETH in Switzerland, H. A. Nour Eldin at the University of Wuppertal in Germany, J. Piechna at Warsaw University of Technology in Poland, P. H. Snyder at Rolls-Royce North American Technologies Inc., and R. Shreeve at the Naval Postgraduate School in the U.S.

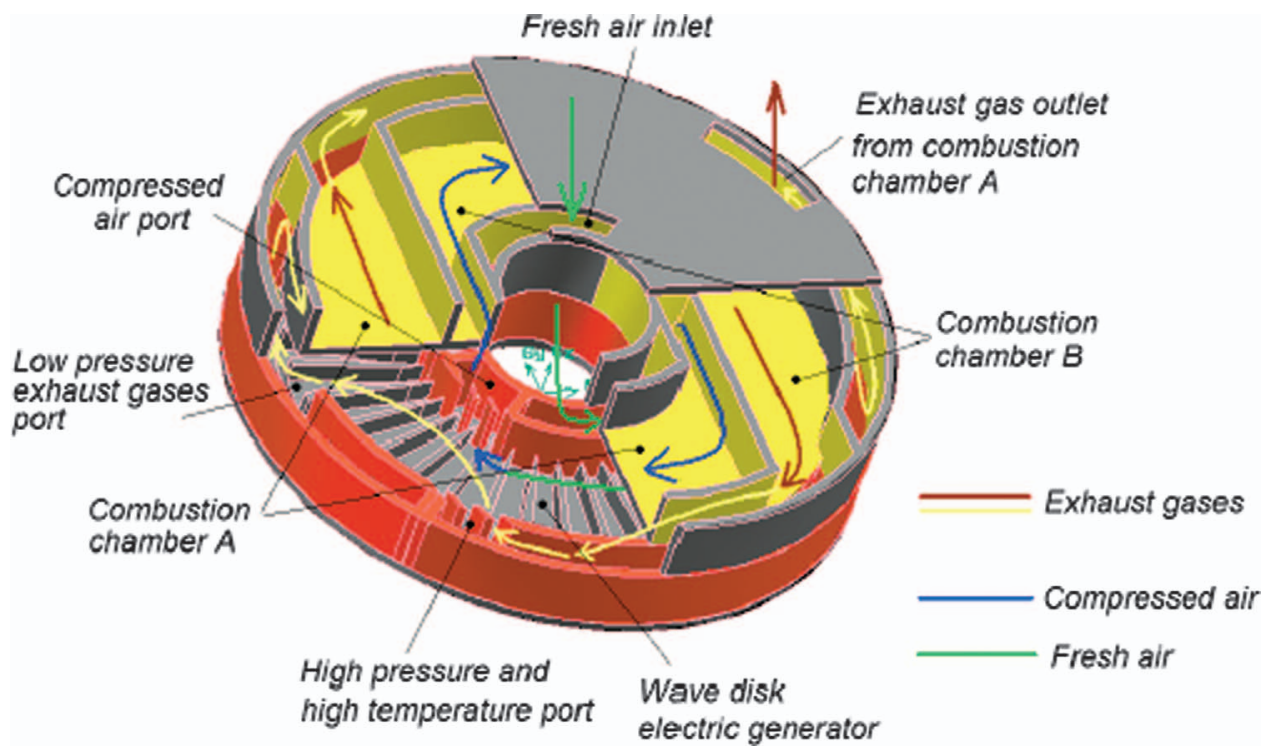

Fig. 25 Conceptual design of an ultra-micro power generator using a radial wave rotor, taken from Ref. [237] 


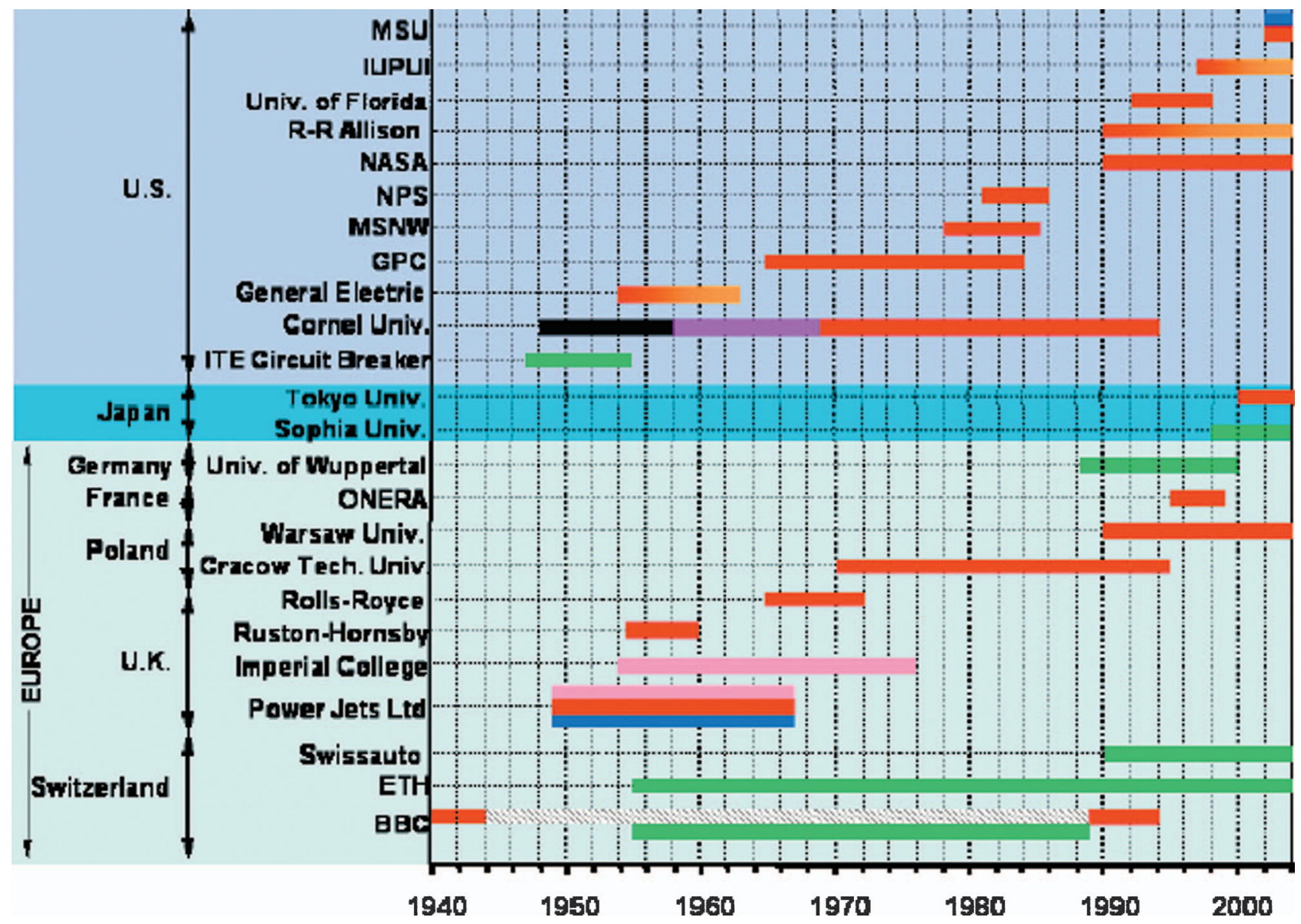

Fig. 26 Historical perspective of wave rotor technology. Red: gas turbine application. Green: IC engine supercharging. Blue: refrigeration cycle. Pink: pressure divider and equalizer. Purple: wave superheater. Orange: internal combustion wave rotors. Black: general applications.

\section{References}

[1] Weber, H. E., 1986, "Shock-Expansion Wave Engines: New Directions for Power Production," ASME Paper 86-GT-62.

[2] Weber, H. E., 1995, Shock Wave Engine Design, John Wiley and Sons, New York.

[3] Iancu, F., and Müller, N., 2005, "Efficiency of Shock Wave Compression in a Microchannel," Journal of Microfluid and Nanofluid, 2(1), pp. 50-63.

[4] Paxson, D. E.,1998, "Wave Augmented Diffusers for Centrifugal Compressors," AIAA Paper 98-3401, also NASA TM-208480.

[5] Darrieus, G., 1950, "Pressure Exchange Apparatus," U.S. Patent 2526618.

[6] Kentfield, J. A. C., 1993, Nonsteady, One-Dimensional, Internal, Compressible Flows, Oxford University Press, Oxford.

[7] Gyarmathy, G., 1983, "How Does the Comprex Pressure-Wave Supercharger Work?," SAE Paper 830234.

[8] Zehnder, G., Mayer, A., and Mathews, L., 1989, "The Free Running Comprex®," SAE Paper 890452.

[9] Hiereth, H., 1989, "Car Tests With a Free-Running Pressure-Wave Charger-A Study for an Advanced Supercharging System," SAE Paper 890453

[10] Welch, G. E., 2000, "Overview of Wave-Rotor Technology for Gas Turbine Engine Topping Cycles," Novel Aero Propulsion Systems International Symposium, The Institution of Mechanical Engineers, London, pp. 2-17.

[11] Snyder, P. H., 1996, "Wave Rotor Demonstrator Engine Assessment," NASA CR-198496.

[12] Snyder, P. H., and Fish, R. E., 1996, “Assessment of a Wave Rotor Topped Demonstrator Gas Turbine Engine Concept," ASME Paper 96-GT-41.

[13] Berchtold, M., 1985, "The Comprex as a Topping Spool in a Gas Turbine Engine for Cruise Missile Propulsion," Proceedings ONR/NAVAIR Wave Rotor Research and Technology Workshop, Report NPS-67-85-008, pp. 284-290, Naval Postgraduate School, Monterey, CA.

[14] Fatsis, A., and Ribaud, Y., 1997, "Numerical Analysis of the Unsteady Flow Inside Wave Rotors Applied to Air Breathing Engines," 13th International Symposium on Airbreathing Engines, Paper ISABE-97-7214.

[15] Mathur, A., 1985 "A Brief Review of the GE Wave Engine Program (19581963)," Proceedings ONR/NAVAIR Wave Rotor Research and Technology Workshop, Report NPS-67-85-008, pp. 171-193, Naval Postgraduate School, Monterey, CA.
[16] Welch, G. E., 1997, "Macroscopic Balance Model for Wave Rotors," J. Propul. Power, 13(4), pp. 508-516; also AIAA Paper 96-0243, and NASA TM107114.

[17] Welch, G. E., Jones, S. M., and Paxson, D. E., 1997, "Wave Rotor-Enhanced Gas Turbine Engines," ASME J. Eng. Gas Turbines Power, 119(2), pp. 469477; also AIAA Paper 95-2799, and NASA TM 106998.

[18] Knauff, R., 1906, "Converting Pressures of Liberated Gas Energy into Mechanical Work," British Patent 2818.

[19] Pearson, R. D., 1982, "Pressure Exchangers and Pressure Exchange Engines," in The Thermodynamics and Gas Dynamics of Internal Combustion Engine Vol. 1, R. Benson, ed., Oxford University Press, Chap. 16, pp. 903-940.

[20] Knauff, R., 1906, "Converting Internal Gas Energy into Mechanical Work," British Patent 8273.

[21] Burghard, H., 1913, British Patent 19421

[22] Lebre, A. F., 1928, British Patent 290669.

[23] Burghard, H., 1929, German Patent 485386.

[24] Kentfield, J. A. C., 1998, "Wave Rotors and Highlights of Their Development," AIAA Paper 98-3248.

[25] Meyer, A., 1947, "Recent Developments in Gas Turbines," Journal of Mechanical Engineering, 69(4), pp. 273-277.

[26] Real, R., 1946, "The 3000 kW Gas Turbine Locomotive Unit," Brown Boveri Rev., 33(10), pp. 270-271.

[27] Meyer, A., 1947, "Swiss Develop New Gas Turbine Units," Electr. World, 127, pp. 38-40.

[28] Azoury, P. H., 1992, Engineering Applications of Unsteady Fluid Flow, John Wiley and Sons, New York.

[29] Rose, P. H., 1979, "Potential Applications of Wave Machinery to Energy and Chemical Processes," Proceedings of the 12th International Symposium on Shock Tubes and Waves, Jerusalem, July 16-19, pp. 3-30.

[30] Seippel, C., 1940, Swiss Patent 225426.

[31] Seippel, C., 1942, Swiss Patent 229280.

[32] Seippel, C., 1946, "Pressure Exchanger," U.S. Patent 2399394.

[33] Seippel, C., 1949, "Gas Turbine Installation," U.S. Patent 2461186.

[34] Berchtold, M., and Gardiner, F. J., 1958, "The Comprex: A New Concept of Diesel Supercharging," ASME Paper 58-GTP-16. 
[35] Berchtold, M., 1958, "The Comprex Diesel Supercharger," SAE Paper No. 63A.

[36] Berchtold, M., and Gull, H. P., 1959, "Road Performance of a Comprex Supercharged Diesel Truck," SAE Paper No. 118U.

[37] Taussig, R. T., and Hertzberg, A., 1984, "Wave Rotors for Turbomachinery," Winter Annual Meeting of the ASME, Machinery for Direct Fluid-Fluid Energy Exchange, edited by J. F. Sladky, AD-07, pp. 1-7.

[38] Doerfler, P. K., 1975, "Comprex Supercharging of Vehicle Diesel Engines,' SAE Paper 750335.

[39] Schruf, G. M., and Kollbrunner, T. A., 1984, "Application and Matching of the Comprex Pressure-Wave Supercharger to Automotive Diesel Engines," SAE Paper 840133.

[40] Zehnder, G., and Mayer, A., 1984, "Comprex® Pressure-Wave Supercharging for Automotive Diesels-State-of-the-Art," SAE Paper 840132.

[41] Berchtold, M., 1985, "The Comprex®," Proceedings ONR /NAVAIR Wave Rotor Research and Technology Workshop, Naval Postgraduate School, Monterey, CA, Report NPS-67-85-008, pp. 50-74.

[42] Azoury, P. H., 1965-1966, "An Introduction to the Dynamic Pressure Exchanger," Proc. Inst. Mech. Eng., 180(18), Part 1, pp. 451-480.

[43] Guzzella, L., Wenger, U., and Martin, R., 2000, "IC-Engine Downsizing and Pressure-Wave Supercharging for Fuel Economy," SAE Paper 2000-01-1019.

[44] Mayer, A., Oda, J., Kato, K., Haase, W., and Fried, R., 1989, "Extruded Ceramic-A New Technology for the Comprex® Rotor," SAE Paper 890453

[45] Guzzella, L., and Martin, R., 1998, "The Save Engine Concept," MTZ Report 10, pp. 9-12.

[46] Burri, H., 1958, "Nonsteady Aerodynamics of the Comprex Supercharger," ASME Paper 58-GTP-15.

[47] Wunsch, A., 1971, "Fourier-Analysis Used in the Investigation of Noise Generated by Pressure Wave Machines," Brown Boveri Rev., 71(4-5).

[48] Croes, N., 1977, "The Principle of the Pressure-Wave Machine as Used for Charging Diesel Engines," Proceedings of the 11th International Symposium on Shock Tubes and Waves, Seattle, July 11-14, pp. 36-55

[49] Summerauer, I., Spinnler, F., Mayer, A., and Hafner, A., 1978, "A Comparative Study of the Acceleration Performance of a Truck, Diesel Engine With Exhaust-Gas Turbocharger and With Pressure-Wave Supercharger Comprex®," The Institution of Mechanical Engineers, London, Paper C70/78.

[50] Kollbrunner, T. A., 1980, "Comprex Supercharging for Passenger Diesel Car Engines," SAE Paper 800884.

[51] Jenny, E., and Zumstein, B., 1982, "Pressure Wave Supercharger of Passenger Car Diesel Engines," The Institution of Mechanical Engineers, London, Paper C44/82.

[52] Keller, J. J., 1984, "Some Fundamentals of the Supercharger Comprex," Presented at Winter Annual Meeting of the ASME, Machinery for Direct FluidFluid Energy Exchange, edited by J. F. Sladky, Jr., AD-07, pp. 47-54.

[53] Rebling, P., and Jaussi, F., 1984, "Field Experience with a Fleet of Test Cars Equipped with Comprex Supercharged Engines," Institution of Mechanical Engineers, London, Paper C442/84; also: SAE Paper 841308.

[54] Schneider, G., 1986, "Comprex ${ }^{\circledR}$ Pressure Wave Supercharger in an Opel Senator with 2.3 Liter Diesel Engine," Brown Boveri Rev., 73(10), pp. 563565.

[55] Zehnder, G., 1971, "Calculating Gas Flow in Pressure-Wave Machines," Brown Boveri Rev., 71(4-5), pp. 172-176.

[56] Mayer, A., and Schruf, G., 1982, "Practical Experience with Pressure Wave Supercharger Comprex on Passenger Cars," The Institution of Mechanical Engineers, London, Paper C110/82.

[57] Zehnder, G., and Mayer, A., 1986, "Supercharging with Comprex to Improve the Transient Behavior of Passenger Car Diesel Engines," SAE Paper 860450.

[58] Spinnler, F., and Jaussi, F. A., 1986, "The Fully Self-Regulated Pressure Wave Supercharger Comprex for Passenger Car Diesel Engines," The Institution of Mechanical Engineers, London, Paper C124/86.

[59] Jenny, E., Moser, P., and Hansel, J., 1986, "Progress with Variable Geometry and Comprex," Institution of Mechanical Engineers Conference, London, $\mathrm{Pa}$ per C109/86.

[60] Jenny, E., and Naguib, M., 1987, "Development of the Comprex PressureWave Supercharger: In the Tradition of Thermal Turbomachinery," Brown Boveri Rev., 74(8), pp. 416-421.

[61] Mayer, A., 1987, "The Comprex Supercharger-A Simple Machine for a Highly Complex Thermodynamic Process," Brown Boveri Rev., 74(8), pp. 422-430.

[62] Zehnder, G., and Müller, R., 1987, "Comprex Pressure-Wave Supercharger for Car Diesel Engines,” Brown Boveri Rev., 74(8), pp. 431-437.

[63] Mayer, A., 1988, "Comprex-Supercharging Eliminates Trade-off of Performance, Fuel Economy and Emissions," SAE Paper 881152.

[64] Mayer, A., and Pauli, E., 1988, "Emissions Concept for Vehicle Diesel Engines Supercharged with Comprex," SAE Paper 880008.

[65] Mayer, A., 1988, "The Free Running Comprex-A New Concept for Pressure Wave Supercharger," SAE Document PC 55.

[66] Amstutz, A., Pauli, E., and Mayer, A., 1990, "System Optimization with Comprex Supercharging and EGR Control of Diesel Engines," SAE Paper 905097.

[67] Mayer, A., Nashar, I., Perewusnyk, J., 1990, "Comprex with Gas Pocket Control," The Institution of Mechanical Engineers, London, Paper C405/032.

[68] Mayer, A., Pauli, E., and Gygax, J., 1990, "Comprex (R) Supercharging and Emissions Reduction in Vehicles Diesel Engines," SAE Paper 900881.

[69] Barry, F. W., 1950, "Introduction to the Comprex," ASME J. Appl. Mech., March, pp. 47-53.

[70] Lutz, T. W., and Scholz, R., 1968, "Supercharging Vehicle Engines by the Comprex System,” The Institution of Mechanical Engineers, London, October
[71] Berchtold, M., and Lutz, T. W., 1974, "A New Small Power Output Gas Turbine Concept," ASME Paper 74-GT-111.

[72] Berchtold, 1974, "The Comprex Pressure Exchanger: A New Device for Thermodynamic Cycles," JSAE Paper, Tokyo.

[73] Eisele, E., Hiereth, H., and Polz, H., 1975, "Experience with Comprex Pressure Wave Supercharger on the High-Speed Passenger Car Diesel Engine," SAE Paper 750334

[74] Groenewold, G. M., Welliver, D. R., and Kamo, R., 1977, "Performance and Sociability of Comprex Supercharged Diesel Engine," ASME Paper 77 DGP-4.

[75] Schwarzbauer, G. E., 1978, "Turbocharging of Tractor Engines with Exhaust Gas Turbochargers and the BBC-Comprex," The Institution of Mechanical Engineers, London, Paper C69/78.

[76] Walzer, P., and Rottenkolber, P., 1982, "Supercharging of Passenger Car Diesel Engines," The Institution of Mechanical Engineers, London, Paper C117/82.

[77] Wallace, F. J., and Aldis, C. A., 1982, "Comprex Supercharging Versus Turbocharging of a Large Truck Diesel Engine," The Institution of Mechanical Engineers, London, Paper C39/82.

[78] Hong-De, J., 1983, "Two-Dimensional Unsteady Flow in Comprex Rotor," Tokyo International Gas Turbine Congress, Paper 83-Tokyo-IGTC-59.

[79] Zhang, H. S., and So, R. M., 1990, "Calculation of the Material Interface in a Pressure-Wave Supercharger," Proc. Inst. Mech. Eng., Part A, 204(A3), pp. $151-161$.

[80] Hitomi, M., Yuzuriha, Y., and Tanake, K., 1989, "The Characteristics of Pressure Wave Supercharged Small Diesel Engine," SAE Paper 89054

[81] Zauner, E., Chyou, Y. P., Walraven, F., and Althaus, R., 1993, "Gas Turbine Topping Stage Based on Energy Exchangers: Process and Performance,' ASME Paper 93-GT-58.

[82] Anonymous, 1997, "A Pressure-Wave Machine with Integrated ConstantVolume Combustion,” NEFF Funding of Swiss Energy Research 1977-1997, Project No. 426, pp. 142-153.

[83] Nalim, M. R., and Pekkan, K., 2003, "Internal Combustion Wave Rotors for Gas Turbine Engine Enhancement," ASME Paper IGTC-2003-FR-303.

[84] Nalim, M. R., and Pekkan, K., 2003, "A Review of Rotary Pressure-Gain Combustion Systems for Gas Turbine Applications," ASME Paper GT-200338349.

[85] Nour Eldin, H. A., Oberhem, H., and Schuster, U., 1987, "The Variable GridMethod for Accurate Animation of Fast Gas Dynamics and Shock-Tube Like Problems," Proceedings of the IMACS/IFAC International Symposium on Modeling and Simulation of Distributed Parameter Systems, Japan, pp. 433440.

[86] Oberhem, H., and Nour Eldin, H. A., 1990, "Fast and Distributed Algorithm for Simulation and Animation of Pressure Wave Machines," Proceedings of the IMACS International Symposium on Mathematical and Intelligent Models in System Simulation, Belgium, pp. 807-815.

[87] Oberhem, H., and Nour Eldin, H. A., 1991, "A Variable Grid for Accurate Animation of the Nonstationary Compressible Flow in the Pressure Wave Machine," 7th International Conference on Numerical Methods in Laminar and Turbulent Flow, U.S.

[88] Nour Eldin, H. A., and Oberhem, H., 1993, "Accurate Animation of the Thermo-Fluidic Performance of the Pressure Wave Machine and its Balanced Material Operation," 8th International Conference on Numerical Methods in Laminar and Turbulent Flow, UK.

[89] Markarious, S. H., Nour Eldin, H. A., and Pu, H., 1995, "Inverse Problem Approach for Unsteady Compressible Fluid-Wave Propagation in the Comprex," 9th International Conference on Numerical Methods in Laminar and Turbulent Flow, U.S

[90] Oberhem, H., and Nour Eldin, H. A., 1995, "Accurate Animation of the Thermo-Fluidic Performance of the Pressure-Wave Machine and its Balanced Material Operation,” Int. J. Numer. Methods Heat Fluid Flow, 5(1), pp. 6374.

[91] Markarious, S. H., Hachicho, O. H., and Nour Eldin, H. A., 1997, "WaveControl Modeling in the Pressure-Wave Supercharger Comprex," 10th International Conference on Numerical Methods in Laminar and Turbulent Flow, UK.

[92] Piechna, J., 1998, "Comparison of Different Methods of Solution of Euler Equations in Application to Simulation of the Unsteady Processes in Wave Supercharger," The Archive of Mechanical Engineering, 45(2), pp. 87-106.

[93] Piechna, J., 1998, "Numerical Simulation of the Comprex Type of Supercharger: Comparison of Two Models of Boundary Conditions," The Archive of Mechanical Engineering, 45(3), pp. 233-250.

[94] Piechna, J., 1998, "Numerical Simulation of the Pressure Wave Supercharger Effects of Pockets on the Comprex Supercharger Characteristics," The Archive of Mechanical Engineering, 45(4), pp. 305-323.

[95] Piechna, J., and Lisewski, P., 1998, "Numerical Analysis of Unsteady TwoDimensional Flow Effects in the Comprex Supercharger," The Archive of Mechanical Engineering, 45(4), pp. 341-351.

[96] Selerowicz, W., and Piechna, J., 1999, "Comprex Type Supercharger as a Pressure-Wave Transformer Flow Characteristics," The Archive of Mechanical Engineering, 46(1), pp. 57-77.

[97] Elloye, K. J., and Piechna, J., 1999, "Influence of the Heat Transfer on the Operation of the Pressure Wave Supercharger," The Archive of Mechanical Engineering, 46(4), pp. 297-309.

[98] Piechna, J., 1999, "A Two-Dimensional Model of the Pressure Wave Supercharger," The Archive of Mechanical Engineering, 46(4), pp. 331-348.

[99] Oguri, Y., Suzuki, T., Yoshida, M., and Cho, M., 2001, "Research on Adapta- 
tion of Pressure Wave Supercharger (PWS) to Gasoline Engine," SAE Paper 2001-01-0368.

[100] Pfiffner, R., Weber, F., Amstutz, A., and Guzzella, L., 1997, "Modeling and Model based Control of Supercharged SI-Engines for Cars with Minimal Fuel Consumption," Proceedings of the American Control Conference, Vol. 1, pp. 304-308.

[101] Weber, F., and Guzzella, L., 2000, "Control Oriented Modeling of a Pressure Wave Supercharger," SAE Paper 2000-01-0567.

[102] Weber, F., Spring, P., Guzzella, L., and Onder, C., 2001, "Modeling of a Pressure Wave Supercharged SI Engine Including Dynamic EGR Effects," 3rd International Conference on Control and Diagnostics in Automotive Applications, Italy.

[103] Weber, F., Guzzella, L., and Onder, C., 2002, "Modeling of a Pressure Wave Supercharger Including External Exhaust Gas Recirculation,” Proc. Inst Mech. Eng., Part D (J. Automob. Eng.), 216(3), pp. 217-235

[104] Spring, P., Guzzella, L., and Onder, C., 2003, "Optimal Control Strategy for a Pressure-Wave Supercharged SI Engine," ASME Paper ICES2003-645, Austria.

[105] Icingür, Y., Hasimoglu, C., and Salman, M. S., 2003, "Effect of Comprex Supercharging on Diesel Emissions," Energy Convers. Manage., 44, pp. $1745-1753$.

[106] Weatherston, R. C., and Hertzberg, A., 1967, "The Energy Exchanger, A New Concept for High-Efficiency Gas Turbine Cycles," ASME J. Eng. Power, 89, pp. $217-228$

[107] Hendricks, J. R., 1991, "Wave Rotor Diffusers," M.S. thesis, Cornell University, Ithaca, New York.

[108] Mathis, G. P., 1991, "Wave Enhanced Gas Turbine Engine Cycles," M.S thesis, Cornell University, Ithaca, New York.

[109] Nalim, M. R., Moscari, J. C., and Resler, E. L., 1993, "Wave Cycle Design for $\mathrm{NO}_{\mathrm{X}}$ Limited Wave Rotor Core Engines for High Speed Propulsion," ASME Paper 93-GT-426.

[110] Resler, E. L., Moscari, J. C., and Nalim, M. R., 1994, "Analytic Design Methods for Wave Cycles,” J. Propul. Power, 10(5), pp. 683-689; also AIAA Paper 93-2523

[111] Mocsari, J. C., 1994, "Design of Wave Rotor Topping Cycles for Propulsion and Shaftpower," M.S. thesis, Cornell University, Ithaca, New York.

[112] Nalim, M. R., 1994, "Wave Cycle Design for Wave Rotor Engines with Limited Nitrogen-Oxide Emissions," Ph.D. thesis, Cornell University, Ithaca, New York.

[113] Nalim, M. R., and Resler, E. L., 1996, "Wave Cycle Design for Wave Rotor Gas Turbine Engines with Low NO $\mathrm{X}_{\mathrm{X}}$ Emissions," ASME J. Eng. Gas Turbines Power, 118(3), pp. 474-480; also ASME Paper 95-GT-245.

[114] Resler, E. L., 2001, “Shock Wave Propulsion,” Int. J. Chem. Kinet., 33(12), pp. 846-852.

[115] Müller, M. A., 1954, German Patents 916607 and 924845.

[116] Foa, J. V., 1960, Elements of Flight Propulsion, John Wiley and Sons, New York.

[117] Taussig, R. T., 1984, "Wave Rotor Turbofan Engines for Aircraft," Winter Annual Meeting of the ASME, Machinery for Direct Fluid-Fluid Energy Exchange, edited by J. F., Sladky, paper AD-07, pp. 9-45.

[118] Kentfield, J. A. C., 1985, "The Pressure Exchanger, An Introduction Including a Review of the Work of Power Jets (R \& D) Ltd.," Proceedings ONR/ NAVAIR Wave Rotor Research and Technology Workshop, Naval Postgraduate School, Monterey, CA, Report NPS-67-85-008, pp. 9-49.

[119] Jendrassik, G., 1956, "Jet Reaction Propulsion Units Utilizing a Pressure Exchanger," U.S. Patent 2757509

[120] Jendrassik, G., 1960, "Pressure Exchangers and Applications Thereof," U.S. Patent 2946184.

[121] Spalding, D. B., 1985, "Remarks on the Applicability of Computational Fluid Dynamics to Wave Rotor Technology," Proceedings ONR/NAVAIR Wave Rotor Research and Technology Workshop, Naval Postgraduate School, Monterey, CA, Report NPS-67-85-008, pp. 403-449.

[122] Jonsson, V. K., Matthews, L., and Spalding, D. B., 1973, "Numerical Solution Procedure for Calculating the Unsteady, One-Dimensional Flow of Compressible Fluid," ASME Paper 73-FE-30.

[123] Matthews, L., 1969, "An Algorithm for Unsteady Compressible OneDimensional Fluid Flow,” M.S. thesis, University of London.

[124] Azim, A., 1974, "An Investigation Into the Performance and Design of Pressure Exchangers," Ph.D. thesis, University of London.

[125] Azoury, P. H., and Hai, S. M., 1975, "Computerized Analysis of Dynamic Pressure Exchanger Scavenge Processes," Proc. Inst. Mech. Eng., 189, pp. $149-158$

[126] Azoury, P. H., 1960, "The Dynamic Pressure Exchanger-Gas Flow in a Model Cell," Ph.D. thesis, University of London.

[127] Kentfield, J. A. C., 1963, "An Examination of the Performance of Pressure Exchanger Equalizers and Dividers," Ph.D. thesis, University of London.

[128] Kentfield, J. A. C., 1968, "An Approximation Method for Predicting the Performance of Pressure Exchangers," ASME Paper 68-WA-FE-37.

[129] Kentfield, J. A. C., 1969, "The Performance of Pressure-Exchanger Dividers and Equalizers," ASME J. Basic Eng., 91(3), pp. 361-370.

[130] Kentfield, J. A. C., and Barnes, J. A., 1976, "The Pressure Divider: A Device for Reducing Gas-Pipe-Line Pumping-Energy Requirements," Proceedings of 11th Intersociety Energy Conversion Engineering Conference, pp. 636-643.

[131] Kentfield, J. A. C., 1998, "Circumferential Cell-Dividers in Wave Rotors," AIAA Paper 98-3397.

[132] Pearson, R. D., 1983, “A Pressure Exchange Engine for Burning Pyroil as the
End User in a Cheap Power from Biomass System," 15th International Congress of Combustion Engines, Paris.

[133] Pearson, R. D., 1985, “A Gas Wave-Turbine Engine Which Developed 35 HP and Performed Over a 6:1 Speed Range," Proceedings ONR/NAVAIR Wave Rotor Research and Technology Workshop, Naval Postgraduate School, Monterey, CA, Report NPS-67-85-008, pp. 403-449.

[134] Shreeve, R., Mathur, A., Eidelman, S., and Erwin, J., 1982, "Wave Rotor Technology Status and Research Progress Report," Naval Post-Graduate School, Monterey, CA, Report NPS-67-82-014PR.

[135] Coleman, R. R., 1984, "Wave Engine Technology Development," Final report prepared by General Power Corporation for AFWAL, Contract No. AFWAL-TR-83-2095.

[136] Coleman, R. R., 1994, "Cycle for a Three-Stage Ultrahigh Pressure Ratio Wave Turbine Engine," AIAA Paper 94-2725.

[137] Lear, W. E., 1997, "Advanced Wave Rotor, Fluid-Fluid Exchanger," Phase II report prepared by Unistry Associates for NASA, Contract No. NAS3-27647.

[138] Moritz, R., 1985, "Rolls-Royce Study of Wave Rotors (1965-1970)," Proceedings ONR/NAVAIR Wave Rotor Research and Technology Workshop, Naval Postgraduate School, Monterey, CA, Report NPS-67-85-008, pp. 116124.

[139] Zumdiek, J. F., Thayer, W. J., Cassady, P. E., Taussig, R. T., Christiansen, W. H., and Hertzberg, A., 1979, "The Energy Exchanger in Advanced Power Cycle Systems," Proceedings of the 14th Intersociety Energy Conversion Engineering Conference, Boston.

[140] Thayer, W. J., and Taussig, R. T., 1982, "Erosion Resistance and Efficiency of Energy Exchangers," ASME Paper 82-GT-191.

[141] Zumdiek, J. F., Vaidyanathan, T. S., Klosterman, E. L., Taussig, R. T., Cassady, P. E., Thayer, W. J., and Christiansen, W. H., 1979, "The Fluid Dynamic Aspects of an Efficient Point Design Energy Exchanger," Proceedings of the 12th International Symposium on Shock Tubes and Waves, Jerusalem.

[142] Thayer, W. J., Vaidyanathan, T. S., and Zumdiek, J. F., 1980, "Measurements and Modeling of Energy Exchanger Flow," Proceedings of the 14th Intersociety Energy Conversion Engineering Conference, Seattle.

[143] Thayer, W. J., and Zumdiek, J. F., 1981, "A Comparison of Measured and Computed Energy Exchanger Performance," Proceedings of the 13th International Symposium on Shock Tubes and Waves, Niagara Falls.

[144] Thayer, W. J., 1985, "The MSNW Energy Exchanger Research Program," Proceedings ONR/NAVAIR Wave Rotor Research and Technology Workshop, Naval Postgraduate School, Monterey, CA, Report NPS-67-85-008, pp. 85116.

[145] Taussig, R. T., 1984, "Wave Rotor Turbofan Engines for Aircraft," Mech. Eng. (Am. Soc. Mech. Eng.), 106(11), pp. 60-68.

[146] Mathur, A., 1985, "Design and Experimental Verification of Wave Rotor Cycles," Proceedings ONR/NAVAIR Wave Rotor Research and Technology Workshop, Naval Postgraduate School, Monterey, CA, Report NPS-67-85008, pp. 215-228.

[147] Eidelman, S., Mathur, A., Shreeve, R. P., and Erwin, J., 1984, "Application of Riemann Problem Solvers to Wave Machine Design," AIAA J., 22(7), pp. 1010-1012.

[148] Eidelman, S., 1985, "The Problem of Gradual Opening in Wave Rotor Passages," J. Propul. Power, 1(1), pp. 23-28; also published at the 19th Intersociety Energy Conversion Engineering, San Francisco, California, 1984

[149] Eidelman, S., 1985, "Gradual Opening of Rectangular and Skewed Wave Rotor Passages," Proceedings ONR/NAVAIR Wave Rotor Research and Technology Workshop, Naval Postgraduate School, Monterey, CA, Report NPS67-85-008, pp. 229-2249.

[150] Mathur, A., Shreeve, R. P., and Eidelman, S., 1984, "Numerical Techniques for Wave Rotor Cycle Analysis," American Society of Mechanical Engineers, Fluids Engineering Division (Publication) Vol. 15, presented at the 1984 Winter Annual Meeting of the American Society of Mechanical Engineers, U.S.

[151] Eidelman, S., 1986, "Gradual Opening of Skewed Passages in Wave Rotors," J. Propul. Power, 2(4), pp. 379-381.

[152] Mathur, A., 1985, "Wave Rotor Research: A Computer Code for Preliminary Design of Wave Diagrams," Naval Postgraduate School, Monterey, CA, Report NPS67-85-006CR.

[153] Mathur, A., and Shreeve, R. P., 1987, "Calculation of Unsteady Flow Processes in Wave Rotors," AIAA Paper 87-0011.

[154] Mathur, A., 1986, "Code Development for Turbofan Engine Cycle Performance With and Without a Wave Rotor Component," Naval Postgraduate School, Monterey, CA, Report NPS67-86-006CR.

[155] Mathur, A., 1986, "Estimation of Turbofan Engine Cycle Performance With and Without a Wave Rotor Component," Naval Postgraduate School, Monterey, CA, Report NPS67-86-008CR.

[156] Roberts, J. W., 1990, "Further Calculations of the Performance of Turbofan Engines Incorporating a Wave Rotor," M.S. thesis, Naval Postgraduate School, CA.

[157] Salacka, T. F., 1985, "Review, Implementation and Test of the QAZID Computational Method with a View to Wave Rotor Applications," M.S. thesis, Naval Postgraduate School, CA.

[158] Johnston, D. T., 1987, "Further Development of a One-Dimensional Unsteady Euler Code for Wave Rotor Applications," M.S. thesis, Naval Postgraduate School, CA.

[159] Shreeve, R. P., and Mathur, A., 1985, Proceedings ONR/NAVAIR Wave Rotor Research and Technology Workshop, Naval Postgraduate School, Monterey, CA, Report NPS-67-85-008.

[160] Wilson, J., and Paxson, D. E., 1993, "Jet Engine Performance Enhancement 
Through Use of a Wave-Rotor Topping Cycle," NASA TM-4486.

[161] Welch, G. E., 1997, "Wave Engine Topping Cycle Assessment," AIAA Paper 97-0707; also NASA TM-107371.

[162] Welch, G. E., and Paxson, D. E., 1998, "Wave Turbine Analysis Tool Development," AIAA Paper 98-3402; also NASA TM-208485.

[163] Paxson, D. E., 1992, "A General Numerical Model for Wave-Rotor Analysis," NASA TM-105740.

[164] Paxson, D. E., 1993, "An Improved Numerical Model for Wave Rotor Design and Analysis," AIAA Paper 93-0482; also NASA TM-105915.

[165] Paxson, D. E., 1995, "Comparison Between Numerically Modeled and Experimentally Measured Wave-Rotor Loss Mechanism," J. Propul. Power, 11(5), pp. 908-914; also AIAA Paper 93-2522 and NASA TM-106279.

[166] Wilson, J., and Fronek, D., 1993, "Initial Results from the NASA-Lewis Wave Rotor Experiment," AIAA Paper 93-2521, also NASA TM-106148.

[167] Wilson, J., 1997, "An Experiment on Losses in a Three Port Wave-Rotor," NASA CR-198508.

[168] Wilson, J., 1998, “An Experimental Determination of Loses in a Three-Port Wave Rotor,” ASME J. Eng. Gas Turbines Power, 120(4), pp. 833-842; also ASME Paper 96-GT-117, and NASA CR-198456.

[169] Welch, G. E., and Chima, R. V., 1993, "Two-Dimensional CFD Modeling of Wave Rotor Flow Dynamics," AIAA Paper 93-3318; also NASA TM106261.

[170] Welch, G. E., 1993, "Two-Dimensional Numerical Study of Wave-Rotor Flow Dynamics," AIAA Paper 93-2525.

[171] Welch, G. E., 1997, "Two-Dimensional Computational Model for Wave Rotor Flow Dynamics," ASME J. Eng. Gas Turbines Power, 119(4), pp. 978985; also ASME Paper 96-GT-550, and NASA TM-107192.

[172] Larosiliere, L. M., 1995, "Wave Rotor Charging Process: Effects of Gradual Opening and Rotation," J. Propul. Power, 11(1), pp. 178-184; also AIAA Paper 93-2526, and NASA CR-191157.

[173] Larosiliere, L. M., and Mawid, M., 1995, "Analysis of Unsteady Wave Processes in a Rotating Channel," Int. J. Numer. Methods Fluids, 21(6), pp. 467-488; also AIAA Paper 93-2527, and NASA CR-191154.

[174] Welch, G. E., and Larosiliere, L. M., 1997, "Passage-Averaged Description of Wave Rotor Flow," AIAA Paper 97-3144; also NASA TM-107518.

[175] Paxson, D. E., and Wilson, J., 1995, "Recent Improvements to and Validation of the One Dimensional NASA Wave Rotor Model," NASA TM-106913.

[176] Paxson, D. E., 1998, "An Incidence Loss Model for Wave Rotors with Axially Aligned Passages,” AIAA Paper 98-3251; also NASA TM-207923.

[177] Paxson, D. E., 1996, "Numerical Simulation of Dynamic Wave Rotor Performance," J. Propul. Power, 12(5), pp. 949-957; also AIAA Paper 95-2800, and NASA TM-106997.

[178] Paxson, D. E., and Lindau, J. W., 1997, "Numerical Assessment of Four-Port Through-Flow Wave Rotor Cycles with Passage Height Variation," AIAA Paper 97-3142; also NASA TM-107490.

[179] Paxson, D. E., 1997, "A Numerical Investigation of the Startup Transient in a Wave Rotor,” ASME J. Eng. Gas Turbines Power, 119(3), pp. 676-682; also ASME Paper 96-GT-115, and NASA TM 107196.

[180] Wilson, J., and Paxson, D. E., 1996, "Wave Rotor Optimization for Gas Turbine Topping Cycles," J. Propul. Power, 12(4), pp. 778-785; also SAE Paper 951411, and NASA TM-106951.

[181] Wilson, J., 1997, "Design of the NASA Lewis 4-Port Wave Rotor Experiment," AIAA Paper 97-3139; also NASA CR-202351.

[182] Paxson, D. E., and Nalim, M. R., 1999, "Modified Through-Flow WaveRotor Cycle with Combustor Bypass Ducts," J. Propul. Power, 15(3), pp. 462-467; also AIAA Paper 97-3140, and NASA TM-206971.

[183] Nalim, M. R., and Paxson, D. E., 1999, "Method and Apparatus for Cold-Gas Reinjection in Through-Flow and Reverse-Flow Wave Rotors," U.S. Patent 5894719.

[184] Nalim, M. R., 1995, "Preliminary Assessment of Combustion Modes for Internal Combustion Wave Rotors," AIAA Paper 95-2801;also NASA TM107000; also published in the 1999 ASME ASME J. Eng. Gas Turbines Power, 121(2), pp. 265-271.

[185] Nalim, M. R., and Paxson, D. E., 1997, "A Numerical Investigation of Premixed Combustion in Wave Rotors," ASME J. Eng. Gas Turbines Power, 119(3), pp. 668-675; also ASME Paper 96-GT-116, and NASA TM-107242.

[186] Nalim, M. R., 2000, "Longitudinally Stratified Combustion in Wave Rotors," J. Propul. Power, 16(6), pp. 1060-1068; also AIAA Paper 97-3141, and NASA TM-107513.

[187] Hendricks, R. C., Wilson, J., Wu, T., and Flower, R., 1997, "Bidirectional Brush Seals," ASME Paper 97-GT-256; also NASA TM-107351.

[188] Hendricks, R. C., Wilson, J., Wu, T., Flower, R., and Mullen, R. L., 1997, "Bidirectional Brush Seals - Post-Test Analysis," NASA TM-107501.

[189] Hendricks, R. C., Wilson, J., Wu, T., and Flower, R., 1998, "Two-Way Brush Seals Catch a Wave," Journal of Mechanical Engineering, 120(11), pp. 7880.

[190] Zauner, E., and Spinnier, F., 1994, "Operational behavior of a Pressure Wave Machine with Constant Volume Combustion,” ABB Technical Report.

[191] Keller, J., 1993, "Method for Preparing the Working Gas in a Gas Turbine Installation," U.S. Patent 5,197,276.

[192] Bilgin, M., Keller, J. J., and Breidenthal, R. E., 1998, "Ignition and Flame Propagation Process with Rotating Hot Jets in a Simulated Wave Engine Tes Cell," AIAA Paper 98-3399.

[193] Bilgin, M., 1998, "Stationary and Rotating Hot Jet Ignition Flame Propagation In a Premixed Cell," Ph.D. thesis, University of Washington, Seattle, Washington.

[194] Akbari, P., Baronia, D., and Nalim, M. R., 2006, "Single-Tube Simulation of a Semi-Intermittent Pressure-Gain Combustor," ASME Paper GT200691061.

[195] Gegg, S., and Snyder, P. H., 1998, “Aerodynamic Design of a Wave Rotor to High Pressure Turbine Transition Duct," AIAA Paper 98-3249.

[196] Weber, K., and Snyder, P. H., 1998, "Wave Rotor to Turbine Transition Duct Flow Analysis," AIAA Paper 98-3250.

[197] Snyder, P. H., 2002, "Pulse Detonation Engine Wave Rotor," U.S. Patent 6449939.

[198] Snyder, P. H., Alparslan, B., and Nalim, M. R., 2002, "Gas Dynamic Analysis of the Constant Volume Combustor, A Novel Detonation Cycle," AIAA paper 2002-4069.

[199] Smith, C. F., Snyder, P. H., Emmerson, C. W., and Nalim, M. R., 2002 "Impact of the Constant Volume Combustor on a Supersonic Turbofan Engine," AIAA Paper 2002-3916.

[200] Lear, W. E., and Candler, G., 1993, "Direct Boundary Value Solution of Wave Rotor Flow Fields," AIAA Paper 93-0483.

[201] Lear, W. E., and Candler, G., 1993, "Analysis of the Accuracy of Wave Rotor Boundary Conditions Using a Novel Computational Method," AIAA Paper 93-2524.

[202] Lear, W. E., and Kielb, R. P., 1996, "The Effect of Blade Angle Design Selection on Wave-Turbine Engine Performance," ASME Paper 96-GT-259.

[203] Hoxie, S. S., Lear, W. E., and Micklow, G. J., 1998, "A CFD Study of Wave Rotor Losses Due to the Gradual Opening of Rotor Passage Inlets," AIAA Paper 98-3253.

[204] Fatsis, A., and Ribaud, Y., 1999, "Thermodynamic Analysis of Gas Turbines Topped with Wave Rotors," Aerosp. Sci. Technol., 3(5), pp. 293-299.

[205] Jones, S. M., and Welch, G. E., 1996, "Performance Benefits for Wave RotorTopped Gas Turbine Engines," ASME Paper 96-GT-075.

[206] Fatsis, A., and Ribaud, Y., 1998, "Preliminary Analysis of the Flow Inside Three-Port Wave Rotor by Means of a Numerical Model," Aerosp. Sci. Technol., 2(5), pp. 289-300.

[207] Nalim, M. R., 2003, "Partitioned Multi-Channel Combustor," U.S. Patent 6526936.

[208] Pekkan, K., and Nalim, M. R., 2003, "Two-Dimensional Flow and NO Emissions In Deflagrative Internal Combustion Wave Rotor Configurations," ASME J. Eng. Gas Turbines Power, 125(3), pp. 720-733; also ASME Paper 2002-GT-30085

[209] Pekkan, K., and Nalim, M. R., 2002, "Control of Fuel and Hot-Gas Leakage in a Stratified Internal Combustion Wave Rotor," AIAA Paper 2002-4067.

[210] Pekkan, K., and Nalim, M. R., 2002, "On Alternative Models for Internal Combustor Wave Rotor Simulation," Proceedings of 2002 Technical Meeting of the Central State Section of the Combustion Institute, Knoxville.

[211] Nalim, M. R., and Jules, K., 1998, "Pulse Combustion and Wave Rotors for High-Speed Propulsion Engines," AIAA Paper 98-1614.

212] Nalim, M. R., 2002, "Wave Rotor Detonation Engine," U.S. Patent 6460342

[213] Kailasanath, K., 2003, "Recent Developments in the Research on Pulse Detonation Engines," AIAA J., 14(2), pp. 145-159.

[214] Izzy, Z., and Nalim, M. R., 2001, "Rotary Ejector Enhanced Pulsed Detonation System," AIAA Paper 2001-3613.

[215] Izzy, Z., and Nalim, M. R., 2002, "Wave Fan and Rotary-Ejector Pulsed Performance Prediction," AIAA Paper 2002-4068.

[216] Snyder, P., Alparslan, B., and Nalim, M. R., 2004, "Wave Rotor Combustor Test Rig Preliminary Design,” ASME Paper IMECE2004-61795.

[217] Okamoto, K., and Nagashima, T., 2003, "A Simple Numerical Approach of Micro Wave Rotor Gasdynamic Design," 16th International Symposium on Airbreathing Engines, Paper ISABE-2003-1213.

[218] Okamoto, K., Nagashima, T., and Yamaguchi, K., 2001, "Rotor-Wall Clearance Effects upon Wave Rotor Passage Flow," 15th International Symposium on Airbreathing Engines, Paper ISABE-2001-1222.

[219] Okamoto, K., Nagashima, T., and Yamaguchi, K., 2003, "Introductory Investigation of Micro Wave Rotor," ASME Paper IGTC03-FR-302, Japan.

[220] Okamoto, K., Nagashima, T., and Yamaguchi, K., 2005, "Design and Performance of a Micro Wave Rotor," 17th International Symposium on Airbreathing Engines, Paper ISABE-2005-1270.

[221] Akbari, P., and Müller, N., 2003, "Performance Improvement of Small Gas Turbines Through Use of Wave Rotor Topping Cycles," 2003 International ASME/IGTI Turbo Exposition, ASME Paper GT2003-38772.

[222] Akbari, P., Nalim, M. R., and Müller, N., 2006, "Performance Enhancemen of Microturbine Engines Topped with Wave Rotors," ASME J. Eng. Gas Turbines Power, 128(1), pp. 190-202.

[223] Akbari, P., and Müller, N., 2003, "Performance Investigation of Small Gas Turbine Engines Topped with Wave Rotors," AIAA-Paper 2003-4414.

[224] Dempsey, E., Akbari, P., Müller, N., and Nalim, M. R., 2005, "Optimum Applications of Four-Port Wave Rotors for Gas Turbines Enhancement," 17th International Symposium on Air Breathing Engines, ISABE Paper 20051214

[225] Akbari, P., and Müller, N., 2003, "Preliminary Design Procedure for Gas Turbine Topping Reverse-Flow Wave Rotors," ASME Paper IGTC03-FR301.

[226] Akbari, P., and Müller, N., 2003, "Gas Dynamic Design Analyses of Charging Zone for Reverse-Flow Pressure Wave Superchargers," ASME Paper ICES2003-690.

[227] Akbari, P., 2004, "Performance Prediction and Preliminary Design of Wave Rotors Enhancing Gas Turbine Cycles," Ph.D. thesis, Michigan State University, E. Lansing, MI.

[228] Akbari, P., Kharazi, A. A., and Müller, N., 2003, "Utilizing Wave Rotor 
Technology to Enhance the Turbo Compression in Power and Refrigeration Cycles," ASME Paper IMECE2003-44222.

[229] Kharazi, A. A., Akbari, P., and Müller, N., 2004, "An Application of Wave Rotor Technology for Performance Enhancement of R718 Refrigeration Cycles," AIAA Paper 2004-5636.

[230] Kharazi, A. A., Akbari, P., and Müller, N., 2004, "Performance Benefits of R718 Turbo-Compression Cycles Using a 3-Port Condensing Wave Rotors," ASME Paper IMECE2004-60992.

[231] Kharazi, A. A., Akbari, P., and Müller, N., 2005, "Preliminary Study of a Novel R718 Compression Refrigeration Cycle Using a 3-Port Condensing Wave Rotor," ASME J. Eng. Gas Turbines Power, 127(3), pp. 539-544; also ASME Paper GT2004-53622.

[232] Iancu, F., Akbari, P., and Müller, N., 2004, "Feasibility Study of Integrating Four-Port Wave Rotors into Ultra-Micro Gas Turbines," AIAA Paper 20043581.

[233] Iancu, F., Piechna, J., Dempsey, E., and Müller, N., 2005, "Ultra-Micro Wave Rotor Investigations," 5th International Workshop on Micro Nanotechnology for Power Generation and Energy Conversion Application, PowerMEMS, Tokyo.
[234] Iancu, F., Piechna, J., Dempsey, E., and Müller, N., 2005, "The Ultra-Micro Wave Rotor Research at Michigan State University," 2nd International Symposium on Innovative Aerial/Space Flyer Systems, Tokyo.

[235] Iancu, F., Piechna, J., and Müller, N., 2005, "Numerical Solutions for UltraMicro Wave Rotors," AIAA Paper 2005-5034.

[236] Piechna, J., Akbari, P., Iancu, F., and Müller, N., 2004, "Radial-Flow Wave Rotor Concepts, Unconventional Designs and Applications," ASME Paper IMECE2004-59022.

[237] Piechna, J., 2005, "The Micro Jet Wave Engine Idea," 2nd International Symposium on Innovative Aerial/Space Flyer Systems, Tokyo.

[238] Frąckowiak, M., Iancu, F., Potrzebowski, A., Akbari, P., Müller, N., and Piechna, J., 2004, "Numerical Simulation of Unsteady-Flow Processes in Wave Rotors," ASME Paper IMECE2004-60973.

[239] Iancu, F., 2005, "Integration of a Wave Rotor to an Ultra-Micro Gas Turbine (U $\mu$ GT)," Ph.D. thesis, Michigan State University, E. Lansing, MI.

[240] Akbari, P., and Müller, N., 2005, "Wave Rotor Research Program at Michigan State University," AIAA Paper 2005-3844.

[241] Piechna, J., 2003, “Autonomous Pressure Wave Compressor Device,” International Gas Turbine Congress, ASME Paper IGTC03-FR-305, Japan. 